GEOLOGICAL SURVEY

\title{
MERCURY DISTRIBUTION IN ANCIENT AND MODERN SEDIMENT OF NORTHEASTERN BERING SEA
}

\section{By}

C. Hans Nelson, David E. Pierce, Kam W. Leong, and Frank F. H. Wang

$$
\text { Open-file report }
$$

1972

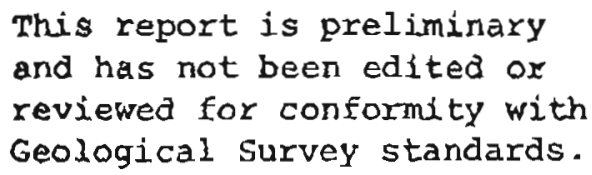

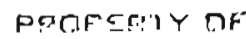

PUELIC I:1

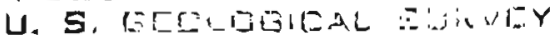

ANCHDRAGE. ALA BKa. 


\section{Conterts}

Page

Abstract-c-n

Introduetion-- 2

Methods of Investigation-- 3

Mercury Distribution-- 6

Discussion-_- 9

sumary of Sedimentary Processes Affecting Mercury Distribution-- 12

\section{Illustrations}

Figure 1. Location of sediment samples and their mercury

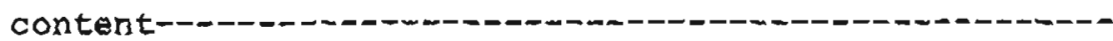

Figure 2. Distribution of surface sediment types and gola anomalies in northeastern Bering sea-----

Figure 3. Frequency distribution of mercury values from northeastern Bexing Sea sediments--

Figure 4. Concentration of mercury in surface and subsurface sediments of different regions in northeastern Bering Sea-n--

Tables

Table 1. Mercury values in replicate splits of different sample typeg-n 6

Table 2. Comparative values of mercury content in surface and subsurface sediments of different bering sea

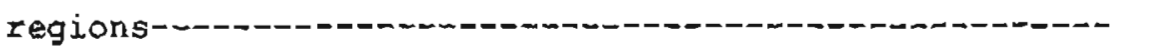

Table 3. Mezcury content (Ppm) of source rocks and unconsolidated sediments in Bering sea other areas---- 10

Appendix

Appendix 1. Sample location and mercury values of Bering Sea sediments-- 18

References Cited-_- 14 
MERCURY DISTRIBUTYON IN ANCIENT AND MODERN SEDIMENT OF NORTHEASTERN BERTNG SEA

\section{By}

C. Hans Nelson, David E. Pierce,

Kar W. Leong, \& Frank F. H. Wang

Abstract

A reconnaissance of surface and subsurface sediments to a maximum depth of 244 foet below the sea floor shows that natural mercury anomalies from 0.2 to 1.3 ppm have been present in nor theastern Bering Sea since early pliocene. The anomalies and mean values are highest in modern boach (maximum 1.3 and mean $0.22 \mathrm{ppm} \mathrm{Hg}$ ) and nearshore subsurface gravels (maximum 0.6 and mean $.06 \mathrm{ppm} \mathrm{Hg}$ ) along the highly mineralized Seward Peninsula and in organic rich silt (maximum 0.16 and mean $0.10 \mathrm{ppm} \mathrm{Hg)} \mathrm{throughout} \mathrm{the} \mathrm{region,} \mathrm{the} \mathrm{mean} \mathrm{values} \mathrm{are} \mathrm{lowest} \mathrm{in}$ offshore sands $(0.03 \mathrm{pgm} \mathrm{Hg})$. Although gold mining may be partially responstble for high mercury levels in the beaches near Nome, Alaska, equally high or greater concentrations of mercury occur in ancient glacial sediments immediately of fshore $(0.6 \mathrm{ppm})$ and in modern unpolluted beach sediments at Bluff $(0.45-1.3 \mathrm{ppm})$; this indicates that the contamination effects of mining may be no greater than natural concentration processes in the Seward peninsula region. The background content of mercury (0.03) throughout the central area of northeastern Bering sea is similar to that elsewhere in the world. The low mean values $(0.04 \mathrm{ppm})$ even immediately offshore from mercury-rich beaches, suggests that in the surface sediments of northeastern Bering sea, the highest concentrations are limited to the beaches near mercury sources, occasionally, however, low mercury anomalies occur offshore in glacial drift derived from mercury source regions of Chukotka and Seward Peninsula and reworked by pleistocene 
shoreline processes. The minimal values offshore may be attributable to beach entrapment of heavy minerals containing mexcury and/or dilution effects of modern sedimentation.

\section{Introduction}

Recent recognition that inorganic mercury in aquatic environments may onter the food chain (Wood and others, 1968) and may eventually concentrate in human tissue (Ackefors, 1971) makes it important to evaluate the concentrations of mercury contained in the sediments of the continental shelves. The distribution of mercury in maxine sediments is not well known (Klein and Goldberg, 1971; U.S. Geological Survey, 1970) nor are the processes or rates of removal from the sediment. A Elrst step in evaluating this potential hazord to man is to establish the level of mercury deposited in sediment by natural processes as opposed to artificial. Defining these concentrations in an area of low population density and minimal industrial activity provides a reference point for studies in developed areas where mercuxy pollution already exists in rivers (de Groot and others, 1971), lakes (Kennedy and others, 1971), and estuaries (McCulloch and others, 1971). This report presents data on mercury in surface and subsurface sediment of a large area of shelf (fig. 1). Natural mercury deposits occur locally in this region (Herreid, 1965; Cobb, 1970, Salnsbury, 1970) and mexcury was also introduced by mining activities, therefore, the amount of mercury distributed by natural processes can be compared to that introduced by man. By analyzing ancient sediments as old as pliocere that lie 244 feet below the sea floor off Nome, the mexcury 
distribution can be established over a period of several million years and the relative effects of recent mining contamination can be evaluated. We would like to acknowledge the beneficial manuscript review and discusgions with Peter Barnes, David Peterson and K. Edward Clifton. We also thank H. Gary Greene, David M. Hopkins, Robert R. Rowland, A. Richard Tagg, and Richard M. Pratt of the U.S. Geologlcal survey for assigtance with sample collection. We also wish to crodit the help of the scientists and crews of the following ships which were involved: $R / V$ THOMPSON (Undversity of Washington), R/V VIRGINIA CITY (NOAA), OSS OCEANOGRAPHER (NOAA), OSS SURVEYOR (NOAA), ANA OSS RAINIER (NOAA). Methods of Investigation

Samples of varying sediments (fIg. 2) were collected on the Bering shelf by Van veen grab samplers, box corers, and placer drills; in selected locations modern beach sediments were channel sampled in the swash, foreshore, and backshore zones (Appendix I). The grab and box corer devices both sampled an area approximately 20 by $30 \mathrm{~cm}$; the grab sampler usually penetrated about $10 \mathrm{~cm}$ and the box corer about $30 \mathrm{~cm}$. Box cores wexe divided into surface $1 \mathrm{~mm}$, surface $0-10 \mathrm{~cm}$, and subsurface 10-45 cm samples. Some of the box cores penetrated older glacial or shoreline deposits. Certain arill holes extended through the pleistocene deposits and into marine sediments that ranged to early pliocene age at 244 feet below the sea floor (Nelson and Hopkins, 1972). Subsamples of consolidated cuttings from each six foot increrent of the three inch diameter drill holes were analyzed. 
The sediment was air dried and gently ground by a hand mortax and pestle in order to volatilize mercury as little as possible. Maxcury content was then determined (Appendix I) by an atomic absorption tachnique, a method in which tho preclaion is \pm 58 or better (Vaughn and Mccarthy, 1964). The lindt of detection was 0.01 ppm using 0.2 gram samples. The average mercury concentrations are reported for samples with more than one analysis.

Two factors were found that affected the accuracy of measurement of the mercury content; these ware particle sparsity effect and combustion of large fragments of organic matter during analysis. Smoke from the burning of a large quantity of organic debris generally deflects the meter off scale on the mercury detector and of course gives erroneously high readings; in three cases it appears that less conspicuous meter deflections from this cause were not detected. Particle sparsity effect results when the analysis for a component such as cinnabar, based on a small split of unprocessed sample, depends more upon the chance occurrence of particles in the analytical portion than upon the actual concentration within the sample (Clifton and others, 1969).

To test for the aforementioned inaccuracies, duplicate splits were run on 30 samples and five splits were analyzed for each of five sample stations where duplicate splits indicated a significant difference. All replicate spits of samples greater than 40 kilometers from the coast and eighty percent of those within 40 kilometers of the shoreline deviate no more than 0.02 ppm mexcury from sample mean values ranging from 0.01 to 
$0.08 \mathrm{ppm}$. From samples taken less than 40 kilometers from the shore, the greatest variance in replicate splits is 0.27 ppm mexcury for a sample with a mean of $0.09 \mathrm{pgr}$; this and two other stations with maximum deviations of $0.2 \mathrm{ppm} \mathrm{Hg}$ from means of $0.08 \mathrm{ppm}$ (see $252 \mathrm{HI}$ in Table 1) are the only instances where split values deviatod more than $0.10 \mathrm{ppm}$ from the mean value of a sample. Sample $252 \mathrm{HI}$ in rable 1 is typical of the three samples with maximum deviations; all show Inconsigtent and markedly decreasing mercury values with increasing time between date of analysis. This differing and declining mercury content with time, in addition to smoke detected in later analyses. suggesto that abnormally large contents of organic materlal affectod the origlnal analyoes of the three samples. Sample 235T in Table 1 is representative of the maximum differences attributable to particle sparsity effects fxom particulate mineral grains of non-oxganic origin. This and the few other such samples with deviations as much as 0.10 ppm generally occur in nearshore ancient and modern beach sands and gravels, particularly near Nome.

It is concluded that no particle sparsity effects are indicated for samples greater than 40 kilometers from shore. Particle sparsity effects are progressively greater toward the shoreline of Seward Peninsula; however, because values generally range from 0.1 to 1.3 ppm mercury in these beaches (fig. 1) and deviation from particle sparsity is 0.10 ppm or less, the relative percent of inaccuracy of analyses is low. Consequently, the patterns of similar values (fig. 1) do appear to be representative 


\begin{abstract}
even though particle sparsity is a minor oampling problem and large organic fragments apparently disrupted analyses of three sample splits.
\end{abstract}

Table 1.-Mercury values in roplicate splits of different gample types. (Sample 2528I, a linnetic peaty clay, exemplifies organic disruption of the analytical instrument, sample 235T, a relict gravel shows particle sparsity of a nearshore sample; and sample 241B, a silty sand, shows variabllity of a typical sample.)

\begin{tabular}{|c|c|c|c|c|}
\hline \multirow{2}{*}{ Split } & \multirow[b]{2}{*}{ Analysis Date } & Number of sample & $\frac{\text { and Mercury }}{235 \mathrm{~T}}$ & \multirow{2}{*}{$\frac{\text { Value in ppm }}{2418}$} \\
\hline & & $252 \mathrm{HI}$ & $235 \mathrm{~T}$ & \\
\hline A & $4 / 6 / 71$ & 0.28 & 0.25 & 0.03 \\
\hline B & $9 / 10 / 71$ & 0.08 & & \\
\hline c & $4 / 29 / 72$ & 0.01 & 0.16 & 0.01 \\
\hline $\mathrm{D}$ & $4 / 29 / 72$ & 0.03 & 0.11 & 0.01 \\
\hline $\mathrm{E}$ & $4 / 29 / 72$ & 0.01 & 0.22 & 0.02 \\
\hline $\mathbf{F}$ & $4 / 29 / 72$ & 0.03 & 0.13 & 0.02 \\
\hline Mean Va & Iue & 0.07 & 0.15 & 0.02 \\
\hline Maximum & Deviation From Mean & 0.21 & 0.10 & 0.01 \\
\hline Average & Deviation From Mean & 0.10 & 0.05 & 0.006 \\
\hline
\end{tabular}

Mercury Distribution

The median, mean, and mode values all equal 0.03 ppm mercury for the 237 samples from the northeastern Bering sea (fig. 3, Table 2). These average values from Bering sea are comparable to those for unconsolidated and presumably uncontaminated aquatic sediments in the few, but widely ranging locatlong elsewhere that have been investigated 
(Table 3). Nearly 90 percent of the values are less than 0.10 ppm mercury and the range from less than 0.01 to 0.1 ppm mercury appears to represent normal values for this region.

With fow exception, intermediate values between 0.11 and $0.2 \mathrm{ppm}$ mercury occur in elther flne-grained sediments with a relatively high organic content or in burled subaerial sediments that often contain peat from relict soils. These values 1 ie well within the expected range of $\mathrm{Hg}$ content assoclated with fine grained sediments (de Groot, 1971), modern solls (Shacklette and others, 1971), and organic rich sediments (Rennedy and others, 1971).

Values greater than 0.2 ppm mexcury from any sediment and greater than 0.1 pPa mercury from sediments low in organic content probably result from concentrations of particulate minerals containing mercury, such as cinnabar. An analysis by the U.S. Bureau of Mines (1967) of a heavy mineral concentrate from Blufe Beach shows 4 percent cinnabar and confirms the presence of such minerals.

All values greater than 0.2 ppm mercury occur within 40 kilometers of the shoreline and the highest contents ( 0.45 to $1.3 \mathrm{ppm})$ occur in the modern beach sediments along southern Seward Feninsula (Table 2). Although mean values $(0.04 \mathrm{ppm})$ of nearshore sediments within $20 \mathrm{~km}$ of the shoreline of Seward Peninsula (flg. 4) are slightly higher than valueg $(0.02 \mathrm{ppm})$ greater than 20 kllometers from the shoreline, all offshore values beyond the shoreline are nearly a factor of ten lower than the Seward Peninsula beaches. Generally high, but normal mean 
Table 2.--Comparative values of mercury content in surface and subsurface sediments of different reglons in northeastern Bering Sea.

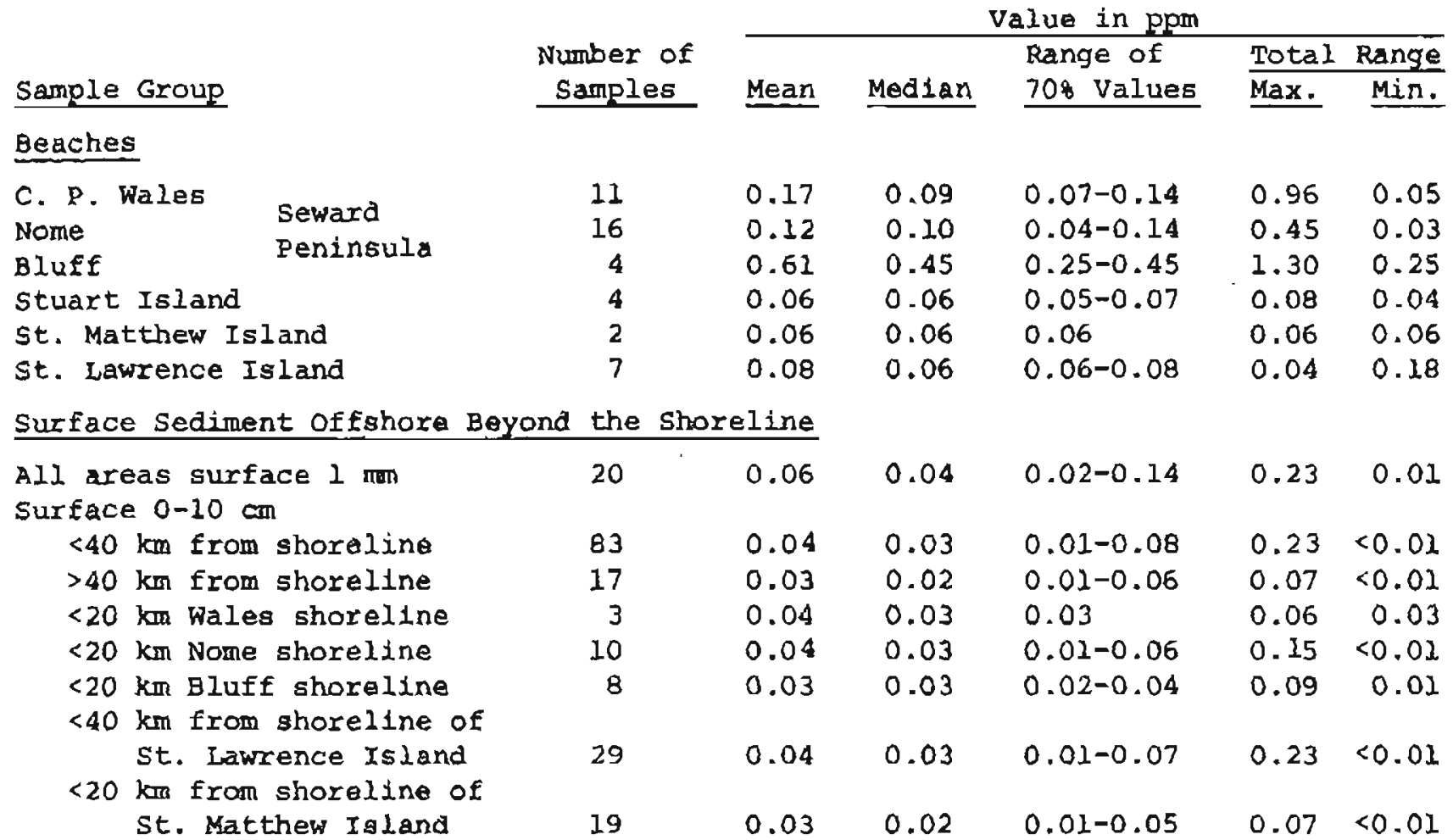

subsurface Sediment offshore Beyond the Shoreline

Box Cores

-10 to $30 \mathrm{~cm}<40 \mathrm{~km}$ shoreldne 2
-10 to $30 \mathrm{~cm}>40 \mathrm{~km}$ shoreline
-10 to $30 \mathrm{~cm}<20 \mathrm{~km}$ Nome "
ome Drill holes

Sediment Type (Surface sediments)

Beach sand and gravel

Relict offshore gravel

Relict offshore pebbly sand

Relict offshore fine sand

Modern or Holocene silt

organic rich clayey silt
26
25
28
15
29
8

Submexged Beaches off Seward Peninsula

-11 to $-13 \mathrm{~m}$

-16 to $-18 m$

-20 to -22 if

-36 to -40 m

rotal NE Bering sea samples

5
3
11
3

237

\footnotetext{
Total NE Bering Sea samples
}

0.04

0.03

0.04

0.06

0.03

0.05

0.03

0.06

0.03

0.22

0.05

0.03

0.03

0.06

0.10

0.03

0.03

0.02

0.04

$0.01-0.09$

0.03

$0.01-0.03$

$0.02-0.06$

0.10

0.03

0.02

0.02

0.03

0.15
0.16

0.04

0.09

0.60

1.30

1.30

0.25

0.11

0.07

0.16

0.16
$<0.01$

0.01

0.01

0.01

237


values of mercury 10.03 to 0.08 , Table 2, fig. 4) are found in the beach and nearshore gediments of Stuart, St. Matthew, and St. Lawrence Islandg which contain no known mercury deposits.

Like surface sediments, the marcury content in subsurface sediments suggests that average values $(0.04 \mathrm{ppm})$ are slightly higher less than 40 kilometers from the shoreline than are average valueg $(0.025$ ppm) more than 40 kilometers from the shoreline (Table 2). The highest mean values occur in the nearghore subsurface sediments off seward peninsula, particularly in drill holeg (fig. 4) off Nome (0.06 ppm). Dril1 holes within 3 miles of Nome penetrated Illinolan glaclal drift (Nelson and Hopkins, 1972) that contalned up to $0.6 \mathrm{ppm}$ mercury and pliocene marine silts more than 200 feet below the sea floor that contained up to 0.15 ppm mercury.

\section{Discussion}

Mercury is consistently abundant in altered zones of seward Peninsula metamorphic rocks (Sainsbury and others, 1970). For example, rocks from the many fault zones of seward Peninsula commonly contain up to several parts per million mercury (Table 3). One such fault zone occurg geveral miles east of the beach on Cape Prince of Wales (Sainsbury, oral commun., 1971) where a high level (0.96 ppm) of mercury was found. Elsewhere, local cinnabar deposits constitute potential sources (cobb, 1970) for mercury (fig. 2). One of these is located in the present beach clife several miles east of the location of high mercury levels ( $1.3-0.45 \mathrm{ppm} H \mathrm{Hg}$ ) on Bluff Beach. The high values 
Table 3.--Mercury content (ppm) of source rocks and unconsolidated sediments in Bering sea other areas.

\begin{tabular}{|c|c|c|c|c|}
\hline \multirow[b]{2}{*}{ Representative Areas } & \multirow[b]{2}{*}{ Reference Source } & \multicolumn{2}{|c|}{ Range } & \multirow{2}{*}{$\begin{array}{l}\text { Average } \\
\text { Background } \\
\text { Level }\end{array}$} \\
\hline & & $\underline{\operatorname{Max}}$ & Min & \\
\hline $\begin{array}{l}\text { Average Sedimentary } \\
\text { Rock }\end{array}$ & Vinogradov, 1959 & & & .04 \\
\hline U.S. Soils & Shacklette \& others, 1971 & 1.5 & .01 & .071 \\
\hline Lake Michigan & Kennedy \& others, 1971 & 0.4 & .02 & $.03-.06$ \\
\hline Rhine River & De Groot others, 1971 & 23.3 & & \\
\hline En River & De Groot \& others, 1971 & 3.3 & .25 & .75 \\
\hline San Francisco Bay & McCulloch others, 1971 & 6.0 & $<.01$ & .35 \\
\hline Guif of California & Blechoff, oral conm., 1972 & .35 & .01 & $.01-.1$ \\
\hline $\begin{array}{l}\text { Pacific Manganese } \\
\text { Nodules }\end{array}$ & Mero, 1965, p. 181 & & & 2.0 \\
\hline Bering sea Area & & & & \\
\hline Seward Peninsula & Sainsbury \& others, 1970 & & & \\
\hline Unaltered Rocks & & .04 & .01 & .03 \\
\hline Altered Rocks & & 10.0 & $<.01$ & .1 \\
\hline streams & & .18 & $<.01$ & .08 \\
\hline $\begin{array}{l}\text { Southwest Alaska } \\
\text { Streams }\end{array}$ & $\begin{array}{l}\text { Clark \& others, 1970a, } \\
\text { 1970b, } 1971\end{array}$ & 20.0 & .01 & $.2-.5$ \\
\hline Goodnews Bay & Barnes, oxal comm., 1972 & .70 & $<.01$ & .03 \\
\hline $\begin{array}{l}\text { Northern Bering } \\
\text { Shelf }\end{array}$ & This report & 1.3 & $<.01$ & .03 \\
\hline $\begin{array}{l}\text { Central Bering } \\
\text { Shelf }\end{array}$ & This report & .07 & $<.01$ & .03 \\
\hline Chukchi sea & Barnes \& Leong, 1971 & .04 & $<.01$ & .02 \\
\hline
\end{tabular}


$(0.2-0.6 \mathrm{ppm})$ found in Illinoian glacial arift, buried offshore from Nome, apparently were derived from material that was eroded from mineralized zones (Sainsbury and others, 1970) Inland from the Nome beaches. Simllarly, the area of high mexcury content $(0.10-0.25 \mathrm{ppm})$ that is found bout $40 \mathrm{~km}$ west from St. Lawrence Island (figs. I and 2) occurs in rellet gravels of glacial drift derived from minerallzed areas in Chukotka (USSR Metalliferous zones Map, 1967).

The high Level of mercury $(0.14-0.45 \mathrm{ppm})$ in the modern Nome beach sand may originate either from glacial drift sources or from the extensive gold mining in the early 1900's. Metallic mercury was used for amalgamating the gold from the beach placers and it can still be panned out of the present beach sediments. The content of mercury $(0.6 \mathrm{ppm})$ in subgurface Neogene sediments off Nome (Table 2) Indicates that the present beach anomalies cannot definitely be attributed to minsing.

Several factors may contribute to the decrease in mercury values of offshore sediment adjacent to beaches. The most likely explanation, paxticulaxly along sewaro Peninsula, is dilution by the great quanttties of Yukon River silt and fine sand that are transported along this coastline (fig. 1; Nelson and others, 2972, MoManus and Smyth, 1970). The modern Yukon sediment blankets the entire area off Bluff, covers the local depressions off Nome and wales, and often is intermixed in the relict sands and gravels of the nearshore zone (Nelson and Hopkins, 1972). 
Normal surf-zone processes tend to concentrate heavy minerals on beaches; light minerals are preferentially winnowed and transported into the nearshore belt of fine sand (Swift and others, 1971). This basic mechanlsm may increase beach content and dilute nearshore content of the particulate mercury bearing minarals like cinnabar which has a relatively high specific gravity. Entrapment of mercury on the beach may be enhanced because the cinnabax may be disgeminated in coarser quartz particles (Allen Clark, personal commun., 1972, 0.S. Geological Survey, Menlo Park CA) as it is elsewhore in Alaska (Clark and otherg, 1971). Such mineral grains containing mercury would be more resistant to breakdown into smaller particles and thus would tend to be concentrated on beaches.

Sunmary of Sedimentary Processes Affecting Mercury Distribution

Glacial transport may provide a means of cazxying mercury-bearing minerals en masse from onshore sourcos to offshore areas. For example, the glacial debris sampled by dxill holes off Nome (Table 2) and located off Northwest Cape of St. Lawxence Island both contain high mercury values (fig. 2). Similar concentrations of othex particulate heavy metals are also found in glacial moraines off Nowe (see gold, fig, 2) ano st. Lawrence Island (see copper, Nelson and Hopkins, 1972). Although the glacial processes would tend to aisperse these particulate minerals as they transport them from theis bedrock sources, secondary enrichment processes occur. Processes of shoreline transgression and regression during the Pleistocene reworked the glacial debris through high energy 
of beach and stream action (Nelson and Hopkins, 1972). Consequently. placer concentrations can be expected in specific localities of thege complex, older sediments in offohore areas; the most likely occurrence of such anomalous concentrations would bo in buried ancient beaches derlved from mercury-bearing glacial arift. The drill holes off Nome appear to have penetrated such deposits.

The distribution of mercury values in the Seward Peninsula region may serve as a preliminary model for dispersal of mercury from natural deposita through the present system of surficial sediments. The average values of mercury in the solis and offshoxe surface sediments of the gouthern Seward Peninsula area are comparable to normal values elsewhere in the world (Table 3). This digtribution of mercury in surflctal sediments suggests that particulate minexals bearing mercury have not been widely dispersed from seward peningula in quantities sufficient to increase offshore mercury levels above normal. The major contamination of present suxficial sediment from natural mercury deposits of Seward peninsula takes place where high energy processes, such as on the beach, can concentrate paxticulate heavy minerals from sources of local lode or alteration zones in bedrock or from displaced glacial debris exposed in shorelines and stream valleys. The apparent shoreline entrapment and concentration of mercury source minerals and/or dilution from recent sediment deposition xesult in normal mercury values even immeaiately offshore from mercury rich beaches. Importance of the dilution factor offshore is emphasized by the observation that both mercury (Table 2) and gold (Nelson and Hopkins, 1972) values are nearly normal in the mixed modern and ancient surficial gediments of the submerged Quaternary beaches off Sowaxd Peninsula. 


\section{REFERENCES CITED}

Ackefors, H., 1971, Mercury pollution in Sweden with special reference to conditions in the water habitat: Proc. Roy. Soc. Lond. B. V. 177, p. $365-387$.

Clark, A. L., Condon, W. H., Hoare, J. M., and Sorg, D. H., 1970, Analyses of rock and stream-sediment samples from the Tayjor Mountains A-6 and southern part of Taylor Mountains B-6 quadrangles, Alaska; 0.5 . Geological Survey Open-file report, 94 . - 1970, Analyses of rock and stream-sediment samples from the Taylor Mountains C-8 quadrangle, Alaska: U.S. Geological Survey Open-file report, $110 \mathrm{p}$. - 1971, Analyses of stream-sediment samples from the Taylor Mountains D-8 quadrangle, Alaska: U.S. Geological survey open-file report, 60 p. Clifton, H. E., Hunter, R. E., Swanson, E. J., and Phillips, R. L., 1969, Sample size and meaningful gold analysis: U.S. Geological Survey Prof. Paper 625-C, p. Cl-C170.

Cobb, E. H., 1970, Mercury Occurrences in Alaska, Mineral Investigations Resources Map MR-54: U.S. Geological Survey, Washington, D.C., I p. cobb, E. H., and Richter, D. H., 1967, Metalilic mineral resources map of the Seward and Blying sound quadrangles, Alaska: U.S. Geological Survey open-file map.

Cobb, E. H., and Sainsbury, C. I., 1968, Metallic mineral resources map of the Teller quadrangle, Alaska: U.S. Geological Survey open-file map. 
De Groot, A. 3., De Goeif, J. J. M., and Zegers, C., 1971, Contents and behavior of mercury as compared with other heavy metals in sediments fxom the rivers Rhine and Ens: Geologie En Mjnbouw, v. 50, p. 393-398. Durovic, S., 1959, Contribution to the log-normal distribution of elements: Geochimical et cosmochimical Acta, v. 15, p. 330-336.

Durum, W. H., Hem, J. D., and Heldel, S. G., 1971, Reconnaissance of selected minor elements in surface waters of the United states, October 1970: U.S. Geological survey Circular 643, p. 1-49. Herreid, G., 1965, Geology of the Bluff Area, Solomon quadrangle, Seward Peninsula, Alaska, Division of Mines and Minerals, Department of Natural Resources, State of Alaska, Geologic Report No. 10, 21 p. Kennedy, E. J., Ruch, R. R., and Shimp, N. F., 1971, Distribution of mercury in unconsolidated sediments from southern Lake Michigan: Illinois Geological Survey Environmental Geology Note 7, 18 p. Klein, D. H., and Goldberg, E. D., 1970, Mercury in the marine environment: Envirommental Sclence and Tech., v. 4, no. 9, p. 765-967. McCulloch, D. S., peterson, D. H., Conomos, T. J., Leong, X. W., and Carlson, P. R., 1971, Mercury distribution in surface sediments, San Francisco Bay Estuary: Transactions, American Geophysical Union, v. 52 , no. 4, p. 361 .

McManus, D. A., and Smyth, C. S., 1970, Turbid bottom water on the continental shelf of the northern Bering Sea: Jour. of Sed. Petrology, v. 40, p. $869-887$.

Mero, J. L., 1965, The mineral resources of the sea: Elsevier Publishing Co., New York, 312 p. 
Nelson, C. H., and Hopkins, D. M., 1972, Sedimentary processes and aistribution of particulate gold in northern Bering sea: U.S. Geological survey Prof. Paper 689, 27 p.

Nelson, C. H., 1971, Trace metal content of surface relict sediments and displacement of northern Bering sea Holocene sediments: Abstracts, Second Cosstal and Shallow water Research Conference, p, 269.

Nelson, C. H., Hopking, D. M., and Scholl, D. W., 1972, Cenozoic sedimentary and tectonlc history of the Bexing sea: in Hood, D. W., and sharma, G. D. Eds.. Proceedings of International symposium for Bering Sea study, 34 p, 13 Eigs., in pregs.

Salnsbury, C. I., and Mackevett, E. M., Jx., 1965, Quicksilver deposits of southwegtern Alaska: U.5. Geological Survey Bull. 2187,89 p. Sainsbury, C. L., Kudson, Travis, Kachadoorian, Reuben, and Richards, Thomas, 1970, Geology, mineral deposits, and geochemical and radiometric anomalies, Serpentine Hot Springs Axea, Sewarō Peninsula, Alakka: U.S. Geological Survey Bull. I312-H, P. HI-H19.

Shacklette, H. T., Boerngen, J. G., and Turner, R. L., 1971, Mercury in the environment - surficial materials of the conterminoug United states: U.S. Geological Survey Circular 644, 5 p.

Swift, D. J. P., Dill, C. E., Jr., and McHone, John, 1971, Hyāraulic fractionation of heavy mineral sultes on an unconsolidated retreating coast: Jour. of Sed. Petrology, v. 41, p. 683-690.

U. S. Bureau of Mines, 1967, Confidential report - Program Data, Joint USBMUSGS Offshore Heavy Metals Project, southern Sewara Poninsula, Alaska: Marine Mineral Technology Center (NOAA), Tiburon, CA., 33 p. 
U. S. Geological Survey, 1970, Mexcury in the environment: U.S. Geological Survey Prof. Paper 713, $67 \mathrm{P}$.

U. S. S. R., Map of basic metalliferous zones in the USSR terxitory, scale 1:7,500,000, 1967: Union Sclentific Research Institute of Geology (VESGEI), Ministry of Geology USSR (in Rassian).

Vaughn, W. W., 1967, A simple mercury vapor detector for geochemical prospecting: U.S. Geological survey Circular 540, $8 \mathrm{p}$.

Vaughn, W. W., and McCarthy, J. H., Jr., 1964, An instrumental technique for the determination of submicrogram concentrations of mercury in solls, rocks and gas: U.S. Geological survey Prof. Paper 501-D, p. D123-D127.

Vinogradov, A. P., 1959, The geochemistry of rare and dispersed chemical elaments in soils: 2nd Edition, New york, Consultants Bureau, 209 p. WedepohI, K. H. [ed.], 1970, Handbook of geochenlstxy: v. 2, no. 2, Springer-Verlag, New York, p. 80-E-1.

Wood, J. M., Scott, K. F., and Rosen, C. G., 1968, Synthesis of methylmexcury compounds by extracts of a metanogenic bacterium: Nature, v. 220 , p. $172-174$. 

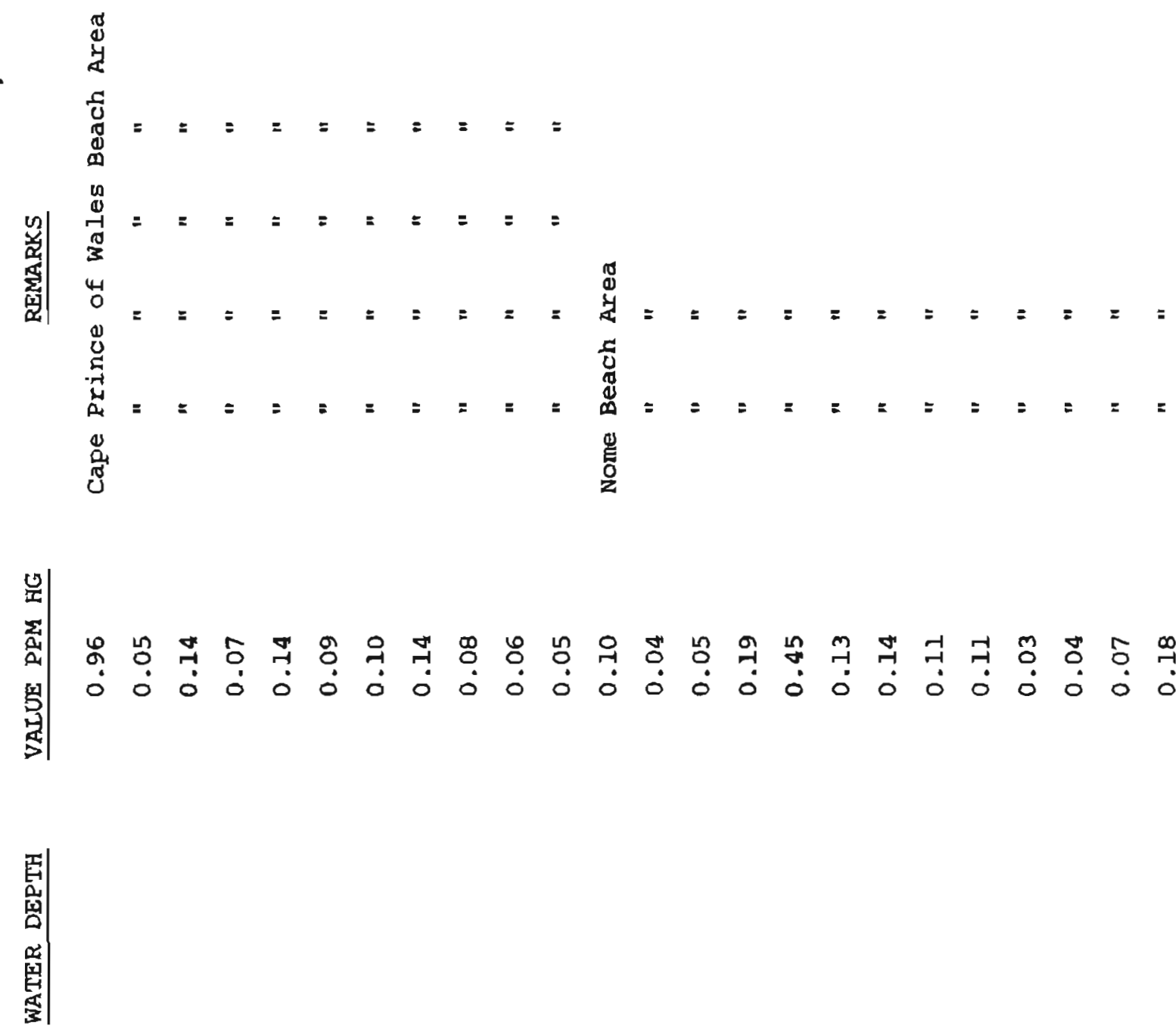

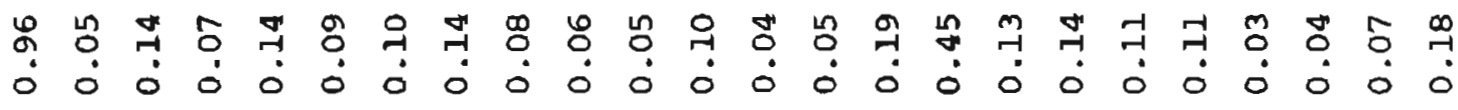

|

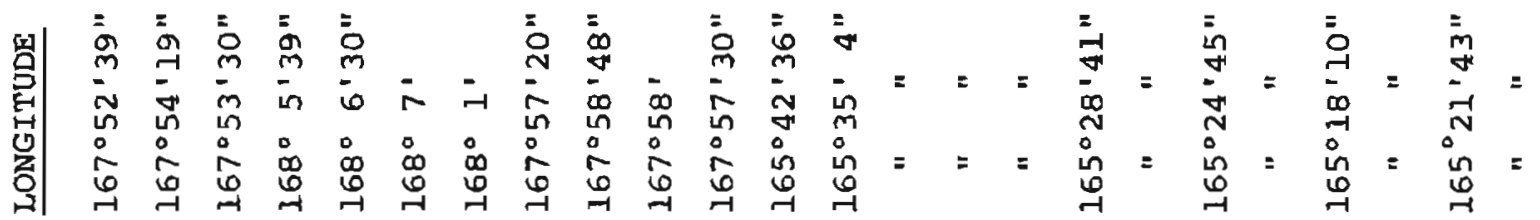

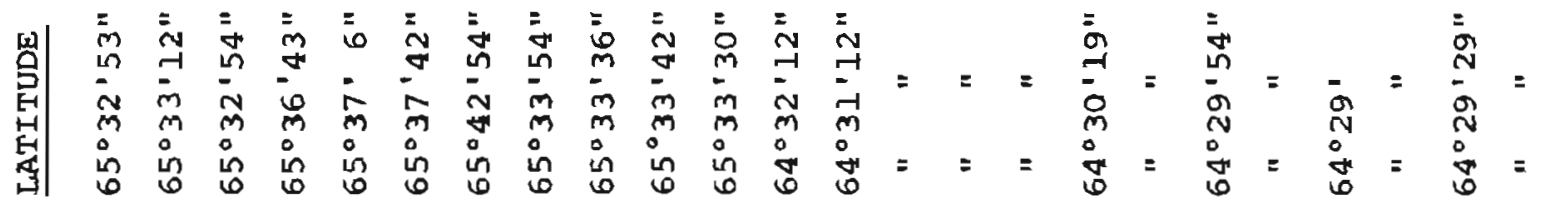

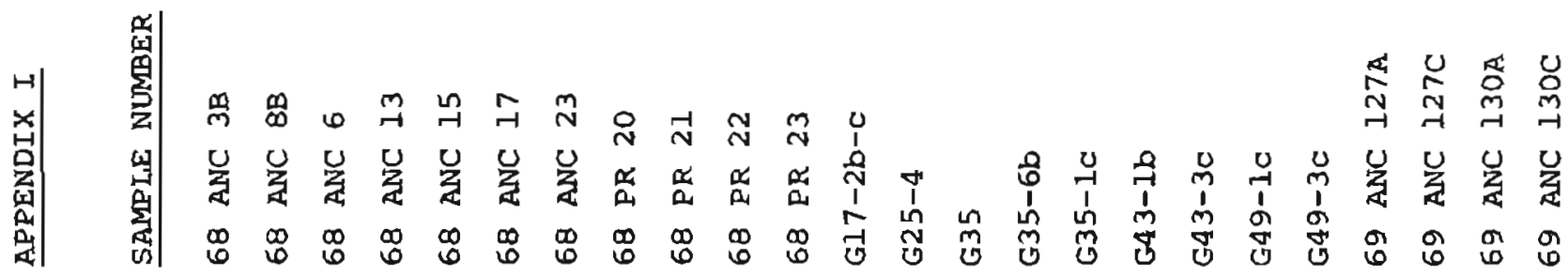




\begin{tabular}{|c|c|c|c|c|c|c|c|c|c|}
\hline SAMPLE NUMBER & LATITUDE & LONGITUDE & WATER DEPTH & VALUE PPM HG & \multicolumn{5}{|c|}{ REMARKS } \\
\hline 69 ANC 145A & $64^{\circ} 26^{\prime} 8^{\prime \prime}$ & $165^{\circ}$ & & 0.08 & Nome Beac & Ch Area & & & \\
\hline 69 ANC $145 \mathrm{C}$ & $"$ & " " " & & 0.10 & $"$ & $"$ & & & \\
\hline 69 ANC $147 \mathrm{~A}$ & $64^{\circ} 27^{\prime} 36^{\prime \prime}$ & $165^{\circ} 8^{\prime} 50^{\prime \prime}$ & & 0.09 & $"$ & $"$ & & & \\
\hline 69 ANC $147 \mathrm{C}$ & $n$ & $" \quad "$ & & 0.08 & $"$ & $n$ & & & \\
\hline $68 \mathrm{AWF}$ 801A & $64^{\circ} 34^{\prime} 40^{\prime \prime}$ & $163^{\circ} 46^{\prime} 7^{\prime \prime}$ & & 0.45 & Bluff Bea & ch Are & & & \\
\hline 68 AWF 802 & $64^{\circ} 34^{\prime} 39^{\prime \prime}$ & $163^{\circ} 45^{*} 30^{\prime \prime}$ & & 0.25 & $"$ & $"$ & & & \\
\hline 68 AWF 807 & $64^{\circ} 34^{\prime} 51^{\prime \prime}$ & $163^{\circ} 49^{\circ} 27^{\prime \prime}$ & & 0.45 & $"$ & $"$ & & & \\
\hline 68 AMF 827 & $64^{\circ} 34^{\prime} 39^{\prime \prime}$ & $163^{\circ} 46^{\circ} 52^{\prime \prime}$ & & 1.3 & “ & " & & & \\
\hline 69 ANC 85 & $64^{\circ} 37^{\prime} 26^{\prime \prime}$ & $162^{\circ} 27^{\prime} 44^{\prime \prime}$ & & 0.08 & stuart Is & land $E$ & Beach & - North Si & Lde \\
\hline 69 ANC 86 & $54^{\circ} 37^{\prime} 26^{\prime \prime}$ & $162^{\circ} 27^{\circ} 44^{\mathrm{n}}$ & & 0.05 & " & 1 & " & " & \\
\hline 69 ANC 95 & $63^{\circ} 37^{\prime} 25^{\prime \prime}$ & $162^{\circ} 31^{\prime} 10^{\prime \prime}$ & & 0.07 & $"$ & $"$ & $"$ & $"$ & \\
\hline 69 ANC 97 & $63^{\circ} 37^{\prime} 48^{\prime \prime}$ & $162^{\circ} 32^{\prime} 20^{m}$ & & 0.04 & $"$ & $n$ & " & $"$ & \\
\hline 7LADE 3 & & & & 0.06 & st. Mattr & hew Isl & Land $B$ & Beach & \\
\hline $71 \mathrm{ADE} 7$ & & & & 0.06 & $n$ & $\pi$ & " & & \\
\hline USBM $6-1$ & $64^{\circ} 28^{\prime} 54^{\prime \prime}$ & $165^{\circ} 25^{\prime} 26^{\prime \prime}$ & $v 40^{\prime}$ & 0.04 & Offshore & Drill & Hole & $0^{1}-6^{\prime}$ & Depth \\
\hline USBM $6-2$ & $"$ & $"$ & $"$ & 0.02 & $"$ & " & i' & $6^{\prime}-18^{\prime}$ & H \\
\hline USBM $6-4$ & $"$ & $"$ & $"$ & 0.03 & $"$ & $"$ & $"$ & $24^{\prime}-30^{\prime}$ & $"$ \\
\hline USBM $6-6$ & $"$ & " " & $"$ & 0.05 & $"$ & $"$ & $"$ & $36^{\prime}-42^{\prime}$ & " \\
\hline USBM $12-7$ & $64^{\circ} 28^{\prime} 13^{\prime \prime}$ & $165^{\circ} 33^{\prime} 2^{\mu}$ & $\checkmark 58^{\prime}$ & 0.04 & $"$ & $n$ & " & $34^{r}-40^{r}$ & 13 \\
\hline USBM $12-9$ & $"$ & $"$ & $"$ & 0.08 & $"$ & $"$ & $n$ & $46^{\prime}-52^{\prime}$ & $"$ \\
\hline USBM $12-11$ & $n$ & "s & $"$ & 0.04 & $"$ & $"$ & $"$ & $58^{\prime}-64^{\prime}$ & $"$ \\
\hline USBM $12-13$ & $"$ & $"$ & $"$ & 0.09 & $"$ & $"$ & $"$ & $76^{\prime}-82^{\prime}$ & $"$ \\
\hline USBM $12-14$ & $"$ & $"$ & $"$ & 0.04 & n & $"$ & $"$ & $82^{\prime}-88^{\prime}$ & " \\
\hline USBM $12-16$ & $1 "$ & $"$ & $"$ & 0.06 & $"$ & $"$ & $"$ & $94^{\prime}-100^{\prime}$ & $"$ \\
\hline
\end{tabular}




\begin{tabular}{|c|c|c|c|c|c|c|c|c|c|}
\hline SAMELE NUMBER & LATITUDE & LONGITUDE & WATER DEPTH & VALUE PPM HG & \multicolumn{5}{|c|}{ REMARKS } \\
\hline USBM $17-1$ & $64^{\circ} 30^{\prime} 47^{\prime \prime}$ & $165^{\circ} 40^{\prime} 53^{\prime \prime}$ & $m 40^{\prime}$ & 0.04 & Offshore & Drill & Hole & $0^{\prime}-31$ & Depth \\
\hline USEM $17-3$ & $"$ & $"$ & $"$ & 0.01 & $"$ & $"$ & $"$ & $9^{\prime}-21^{\prime}$ & $"$ \\
\hline USBM $17-5$ & " & $" \quad "$ & $"$ & 0.02 & $"$ & $"$ & $"$ & $29^{\prime}-33^{\prime}$ & $"$ \\
\hline USBM $17-9$ & $"$ & $"$ & $"$ & 0.05 & $"$ & $"$ & $"$ & $39^{\prime}-45^{\prime}$ & $"$ \\
\hline USBM $24-5 A$ & $64^{\circ} 24^{\prime} 58^{\prime \prime}$ & $165^{\circ} 12^{\prime} 31^{\prime \prime}$ & $275^{\prime}$ & 0.01 & $"$ & $"$ & $"$ & $42^{\prime}-53^{\prime}$ & $"$ \\
\hline USBM $24-5 B$ & $"$ & $" \quad "$ & $"$ & 0.04 & $"$ & $n$ & $"$ & $42^{\prime}-53^{\prime}$ & $"$ \\
\hline USBM $24-15$ & $"$ & " " " & $n$ & 0.04 & " & 11 & $n$ & $151^{\prime}-162^{\prime}$ & $"$ \\
\hline DSEM $24-20$ & s & $"$ & $n$ & 0.15 & $n$ & 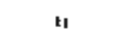 & " & $206^{\prime}-217^{\prime}$ & $n$ \\
\hline $\operatorname{USBM} 24-23$ & $"$ & $" n$ & $s$ & 0.04 & n & " & $n$ & $238^{\prime}-244^{\prime}$ & $n$ \\
\hline USBM $28-13$ & $64^{\circ} 26^{\prime}$ & $165^{\circ} 6^{\circ} 58^{\prime \prime}$ & $v_{4} 7^{\prime}$ & 0.03 & $"$ & $n$ & $n$ & $63^{\prime}-69^{\prime}$ & " \\
\hline USBM $28-15$ & " & $n$ & $"$ & 0.05 & $n$ & $n$ & s & $87^{\prime}-93^{\prime}$ & $m$ \\
\hline USBM $28-17$ & 13 & " & $" 1$ & 0.06 & " & " & " & $100^{\prime}-107^{\prime}$ & $\pi$ \\
\hline USEM $47-2$ & $64^{\circ} 29^{\prime} 39^{\prime \prime}$ & $165^{\circ} 30^{\prime} 56^{n}$ & $\sim 351$ & 0.60 & n & $"$ & $\mathbf{x}$ & $7^{1}-13^{r}$ & $n$ \\
\hline USBM 47-4 & $"$ & $" \quad \cdot "$ & $\pi$ & 0.02 & * & " & $n$ & $19^{\prime}-25^{\prime}$ & " \\
\hline USBM $47-6$ & $"$ & 1 & m & 0.04 & * & $n$ & $"$ & $31^{\prime}-37^{\prime}$ & $"$ \\
\hline USBM $47-8$ & " & " & $n$ & 0.03 & $"$ & n & $"$ & $43^{\prime}-49^{\prime}$ & n \\
\hline USBM $47-10$ & $64^{\circ} 29^{\prime} 39^{\prime \prime}$ & $165^{\circ} 30^{\prime} 56^{\prime \prime}$ & $\sim 35^{\prime}$ & 0.02 & $"$ & $"$ & " & $55^{\prime}-61^{\prime}$ & $"$ \\
\hline USBM $47-12$ & $"$ & " " " & $"$ & 0.05 & $"$ & $"$ & $"$ & $67 '-73^{\prime}$ & $"$ \\
\hline USBM $47-14$ & $"$ & $"$ & $"$ & 0.04 & $"$ & $"$ & $"$ & $79^{\prime}-85^{\prime}$ & $"$ \\
\hline 67 ANC 30 & $64^{\circ} 27^{\prime} 35^{\prime \prime}$ & $165^{\circ} 19^{\prime} 48^{\prime \prime}$ & $45^{\prime}$ & 0.04 & offshore & Surfac & & & \\
\hline 68 AWF 310 & $64^{\circ} 28^{\prime} \theta^{\prime \prime}$ & $164^{\circ} 41^{\prime} 58^{\prime \prime}$ & $31^{\prime}$ & 0.02 & $"$ & $"$ & & & \\
\hline 63 AWF 327 & $64^{\circ} 32^{\prime} 12^{\prime \prime}$ & $164^{\circ} 25^{\circ} 12^{\prime \prime}$ & & 0.02 & $"$ & " & & & \\
\hline 68 AWF 338 & $64^{\circ} 32^{\prime} 41^{\prime \prime}$ & $163^{\circ} 59^{\prime} 50^{\prime \prime}$ & $46^{\prime}$ & 0.03 & " & $"$ & & & \\
\hline 68 AWF 343 & $64^{\circ} 32^{\prime} 48^{\prime \prime}$ & $163^{\circ} 54^{\prime} 18^{\prime \prime}$ & $14^{\prime}$ & 0.03 & $"$ & $"$ & & & \\
\hline
\end{tabular}




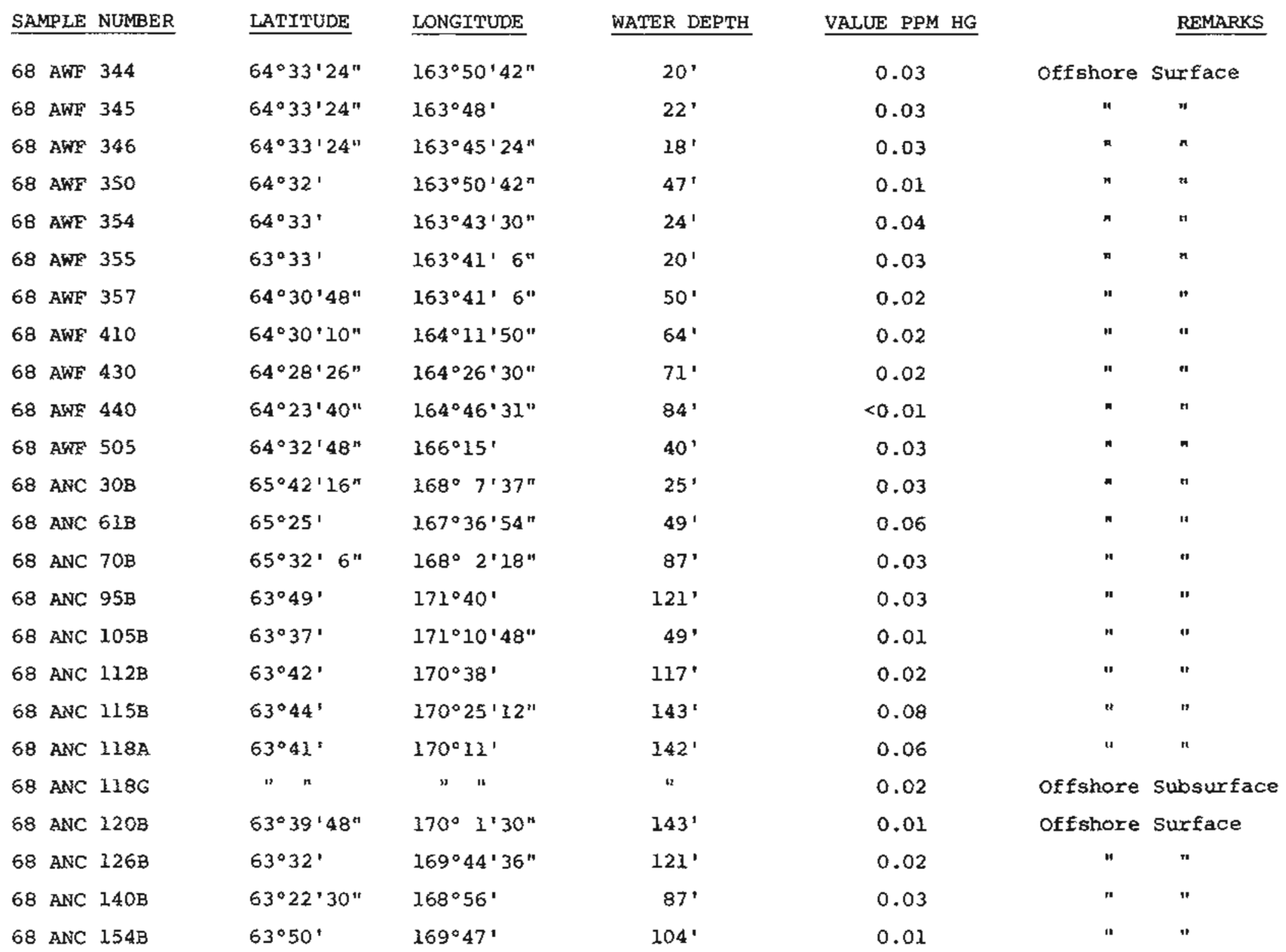




\section{SAMPLE NUMBER}

68 ANC 2668

68 ANC $179 T$

68 ANC $179 \mathrm{~B}$

68 ANC 183B

68 ANC 1828

68 ANC $187 \mathrm{~B}$

68 ANC $190 B$

68 ANC $200 B$

68 ANC $212 \mathrm{~T}$

68 ANC $212 B$

68 ANC $215 B$

68 ANC $216 \mathrm{~A}$

68 ANC 216B

68 ANC 231E

68 ANC 233 B

68 ANC 2343

68 ANC 235T

68 ANC 235T

68 ANC $235 T$

68 ANC $235 \mathrm{~T}$

68 ANC $235 \mathrm{~T}$

68 ANC 235B

68 ANC $235 B$

68 ANC 2358

\section{LATITUDE}

$64^{\circ} 57^{\prime}$

$65^{\circ} 16^{\prime} 12$

$\pi$ It

$65^{\circ} 13^{\prime}$

$65^{\circ} 10^{\prime} 36^{+}$

$65^{\circ} 2^{1} 6^{\prime \prime}$

$64^{\circ} 58^{\prime}$

$64^{\circ} 39^{\prime} 42^{\prime \prime}$

$64^{\circ} 37 \cdot 32^{\prime \prime}$

n

$64^{\circ} 26^{\prime}$

$64^{\circ} 18^{\prime} 30^{n}$

" $M$

$64^{\circ} 20^{\prime} 48^{\prime}$

$64^{\circ} 26^{\prime} 30^{\prime}$

$64^{\circ} 29^{\prime} 54^{n}$

$64^{\circ} 29^{\prime} 30^{\prime \prime}$

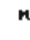

"

"

I:

"

เ)

"

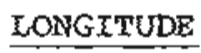

$167^{\circ} 49^{\prime}$

$166^{\circ} 57^{\prime} 12^{\prime \prime}$

$67026^{\prime} 48^{4}$

$167^{\circ} 23^{\prime} 24^{\prime \prime}$

$167^{\circ} 21^{\prime} 5^{m}$

$167^{\circ} 10^{\prime} 30^{\prime}$

$166^{\circ} 36^{\prime} 30^{\prime \prime}$

$167^{\circ} 14^{\prime} 26^{\prime \prime}$

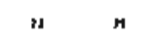

$168^{\circ} 4^{1} 36^{5 *}$

$168^{\circ} 20^{\prime} 48^{\prime \prime}$

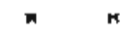

$166^{\circ} \mathrm{B}^{\prime} 24^{\mathrm{H}}$

$166^{\circ} 4^{\prime} 30^{\prime}$

$166^{\circ} 2^{\prime} 18^{\prime \prime}$

$165^{\circ} 45^{\prime} 54^{m}$

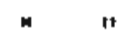

13

" 1

in 3

I

11

"1

\section{WATER DEPTH VAINE PPM EG}

\begin{tabular}{|c|c|}
\hline $136^{\prime}$ & 0.01 \\
\hline $50^{\prime}$ & 0.07 \\
\hline$n$ & 0.04 \\
\hline $69^{\prime}$ & 0.01 \\
\hline $63^{2}$ & 0.01 \\
\hline $76^{1}$ & 0.08 \\
\hline $45^{\prime}$ & 0.03 \\
\hline $72^{\prime}$ & $<0.01$ \\
\hline $96^{1}$ & 0.02 \\
\hline $\mathbf{r}$ & 0.06 \\
\hline $119^{\circ}$ & 0.06 \\
\hline $130^{\circ}$ & 0.02 \\
\hline$n$ & 0.03 \\
\hline $135^{\prime}$ & 0.04 \\
\hline $106^{\prime}$ & 0.03 \\
\hline $67 !$ & 0.02 \\
\hline $66^{\prime}$ & 0.25 \\
\hline " & 0.16 \\
\hline " & 0.11 \\
\hline n & 0.12 \\
\hline м & 0.13 \\
\hline$n$ & 0.36 \\
\hline n & 0.05 \\
\hline H & 0.03 \\
\hline
\end{tabular}

REMARKS

Offshore Surface

Offshore Subsurface

offshore surface

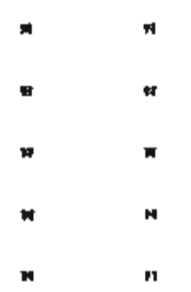

offshore Subsurface

offshore surface

Offshore subsurface

Offshore surface

offshore Surface, Ist Trial

$$
\begin{array}{lll}
* & \text { 2nd Trial } \\
* & \text { " } & \text { 3rd Trial } \\
& \text { " } & 4 \text { th Trial } \\
\text { " } & \text { "th Trial }
\end{array}
$$

Offshore Subsurface, lst Trial

p 1

2nd TriaI

114

3 rd Tial 


\section{SAMPLE NUMBER}

68 ANC 235B

68 ANC 235B

68 ARK $240 B$

68 ANC $241 \mathrm{~T}$

68 ANC $241 \mathrm{~T}$

68 ANC $241 T$

68 ANC 241T

68 ANC 241 T

68 ANC 241B

68 ANC 241B

68 ANC 2418

68 ANC 2418

68 ANC 2418

68 ANC $244 \mathrm{~T}$

68 ANC $244 \mathrm{~B}$

68 ANC $248 B$

68 ANC $251 \mathrm{~B}$

69 ANC 1005

69 ANC 1005

69 ANC 1005

69 ANC $100 \mathrm{~S}$

69 ANC 1005

69 ANC 100BUH

69 ANC IOOBUH

\begin{tabular}{|c|c|c|c|c|c|}
\hline \multicolumn{2}{|c|}{ LATITUDE } & \multicolumn{2}{|c|}{ LONGITUDE } & WATER DEPTH & VALUE PPM \\
\hline \multicolumn{2}{|c|}{$64^{\circ} 29^{\prime} 30^{\prime \prime}$} & \multicolumn{2}{|c|}{$165^{\circ} 45^{\prime} 54^{\prime \prime}$} & $66^{\prime}$ & 0.01 \\
\hline$"$ & $"$ & 1 & $"$ & $"$ & $0.0 \mathrm{X}$ \\
\hline \multicolumn{2}{|c|}{$64^{\circ} 18^{\prime} 12^{\prime \prime}$} & \multicolumn{2}{|c|}{$165^{\circ} 40^{\prime} 12^{r}$} & $69^{\prime}$ & 0.03 \\
\hline \multicolumn{2}{|c|}{$64^{\circ} 24^{\prime}$} & \multicolumn{2}{|c|}{$165^{\circ} 35^{\prime}$} & 102 & 0.11 \\
\hline$"$ & $"$ & $"$ & Ir & $"$ & 0.08 \\
\hline$"$ & $"$ & $"$ & " & $"$ & 0.03 \\
\hline$" 1$ & $"$ & $"$ & " & " & 0.02 \\
\hline$n$ & $n$ & 1 & $n$ & $"$ & 0.02 \\
\hline$"$ & $"$ & $"$ & " & " & 0.03 \\
\hline$"$ & $"$ & H & м & $H$ & 0.01 \\
\hline$n$ & " & "I & 11 & " & 0.01 \\
\hline м & $"$ & ॠ & н & " & 0.02 \\
\hline$"$ & it & 4 & $n$ & " & 0.02 \\
\hline \multicolumn{2}{|c|}{$64^{\circ} 27^{\prime} 24^{n}$} & \multicolumn{2}{|c|}{$165^{\circ} 24^{\prime} 42^{\prime \prime}$} & $69^{\circ}$ & 0.06 \\
\hline n & $*$ & m & 4 & $m$ & 0.01 \\
\hline \multicolumn{2}{|c|}{$64^{\circ} 10^{\prime} 12^{\prime \prime}$} & \multicolumn{2}{|c|}{$165^{\circ} 24^{\prime}$} & $65^{\circ}$ & 0.02 \\
\hline \multicolumn{2}{|c|}{$64^{\circ} 25^{\prime}$} & \multicolumn{2}{|c|}{$165^{\circ} 14^{\prime} 24^{\prime \prime}$} & 71 & $<0.01$ \\
\hline \multicolumn{2}{|c|}{$63^{\circ} 39^{\prime} 12^{\prime \prime}$} & \multicolumn{2}{|c|}{$162^{\circ} 29^{\prime} 6^{\prime \prime}$} & $53^{\prime}$ & 0.14 \\
\hline " & n & +1 & $\$$ & v & 0.03 \\
\hline 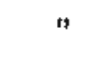 & 4 & $n$ & ต & " & 0.02 \\
\hline$"$ & $"$ & " & " & $"$ & 0.01 \\
\hline "' & " & $"$ & IT & $"$ & 0.02 \\
\hline " & $"$ & ॥ & $"$ & $"$ & 0.14 \\
\hline Ir & $n$ & H & ir & 11 & 0.01 \\
\hline
\end{tabular}

\section{REMARKS}

Offshore Subsurface, 4th Trial

$$
\text { " " } 5 \text { th Trial }
$$

Offshore Surface

offshore surface, lst Trial

$\begin{array}{lll}" & \text { " } & \text { 2nd Trial } \\ \text { " } & \text { " } & \text { 3rd Trial } \\ \text { " } & \text { 4th Trial }\end{array}$

offshore Subsurface, lst Trial

$\begin{array}{lll}* & \text { 2nd Trial } \\ * & \text { " } & \text { " } \\ * & \text { 4th Trial } \\ & \text { 4th Trial }\end{array}$

Offshore surface

offahore subsurface

offshore surface

Offshore Surface, lst Trial

$\begin{array}{lll}\text { " } & \text { " } & \text { 2nd Trial } \\ \text { " } & \text { " } & \text { 4rd Trial } \\ \text { " } & \text { " } & 5 \text { th Trial }\end{array}$

Offshore Upper Subsurface, lst Trial 


\section{SAMPLE NUMBER}

69 ANC 10OBUH

69 ANC 10OBUH

69 ANC $100 B$ UH

69 ANC 10OBEH

69 ANC 10OBLH

69 ANC 100BLH

69 ANC 100BLH

69 ANC 100BEH

69 ANC $101 B$

69 ANC 105B

69 ANC 107B

$\stackrel{5}{\perp} \quad 69$ ANC 114

69 ANC 316

69 ANC 118

69 ANC 1205

69 ANC 120B

69 ANC 121

69 ANC 1225

69 ANC 1220

69 ANC 122L

69 ANC $155 \mathrm{~B}$

69 ANC 20OB

69 ANC 204H III

69 ANC $204 \mathrm{H} \mathrm{I}$

\begin{tabular}{|c|c|c|c|}
\hline \multicolumn{2}{|c|}{ LARITUDE } & \multicolumn{2}{|c|}{ LONGITUDE } \\
\hline $63^{\circ} 39$ & $12 "$ & $162^{\circ}$ & $9^{\prime} 6 " 1$ \\
\hline$"$ & $"$ & $"$ & $"$ \\
\hline " & " & " & " \\
\hline$\because$ & $"$ & $"$ & $"$ \\
\hline$"$ & $"$ & $"$ & $"$ \\
\hline$"$ & $"$ & $"$ & $"$ \\
\hline$"$ & $"$ & $"$ & $"$ \\
\hline 18 & " & " & " \\
\hline
\end{tabular}

$64^{\circ} 9^{\prime} 42^{\text {th }} \quad 164^{\circ} 7^{\prime} 36^{\prime \prime}$

$64^{\circ} 10^{\prime} 36^{\prime \prime} \quad 166^{\circ} 33^{\prime} 42^{\prime \prime}$

$63^{\circ} 52^{\prime}$

$167^{\circ} 18^{\prime} 48^{\prime \prime}$

$62^{\circ} 31^{\prime} 24^{\prime \prime} \quad 165^{\circ} 57^{\prime} 30^{\prime \prime}$

$63^{\circ} 12^{\prime} 30^{\prime \prime} \quad 165^{\circ} 19^{\prime} 42^{\prime \prime}$

$63^{\circ} 45^{\prime} 36^{\prime \prime}$

$166^{\circ} 0^{\prime} 42^{\prime \prime}$

$63^{\circ} 39^{\prime} 30^{\prime \prime}$

$164^{\circ} 37^{\prime}$

" "

$63^{\circ} 35^{\circ} 30^{\prime \prime}$

$163^{\circ} 59^{\prime}$

$64^{\circ} 22^{\prime} 30^{\prime \prime}$

$165^{\circ} 44^{\prime} 48^{\prime \prime}$

17

" $"$

. "

$63^{\circ} 52^{\prime}$

$64^{\circ} 25^{\prime} 48^{\prime \prime}$

$63^{\circ} 46^{\prime} 36^{\prime \prime}$

"

$165^{\circ} 25^{\circ} 16^{\prime \prime}$

$170^{\circ} 1$ ' $30^{\prime \prime}$

\begin{tabular}{c} 
WATER DEPTH \\
\hline $53^{\prime}$ \\
$"$ \\
$"$ \\
$"$ \\
$"$ \\
$"$ \\
$"$ \\
$74^{\prime}$ \\
$95^{\prime}$ \\
$110^{\prime}$ \\
$44^{\prime}$ \\
$42^{\prime}$ \\
$88^{\prime}$ \\
$42^{\prime}$ \\
$"$ \\
$47^{\prime}$ \\
$88^{\prime}$ \\
4 \\
11 \\
$110^{\prime}$ \\
$39^{\prime}$ \\
$141^{\prime}$ \\
$\prime$ \\
\hline
\end{tabular}

VAT,UE PPM HG

0.02

0.04

0.02

0.05

0.02

0.03

0.02

0.06

0.03

0.02

0.01

0.03

0.06

0.02

0.02

0.01

0.16

0.05

0.01

0.01

0.01

0.02

0.04

0.03

\section{REMARKS}

Offshore Upper Subsurface, 3xd Trial

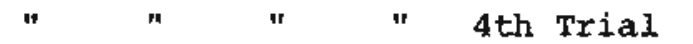

" " " "5th Trial

offshore Lower Subsurface, lst Trial

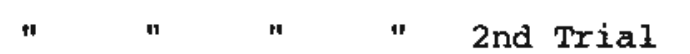

" " " 3rd Trial

" " " $\quad 4$ th Trial

" " "5th Trial

OfEshore Surface

ค

n s

"

(1)

n $\quad$ m

Offshore subsurface

Offshore Surface

\section{Offshore Subsurface}

offshore surface

$n$

offshore subsurface 


\section{SAMPLE NUMBER}

69 ANC 2065

69 ANC $206 \mathrm{~B}$

69 ANC 207

69 ANC 207

69 ANC 207

69 ANC 2088

69 ANC $209 B$

69 ANC 215

69 ANC 215

69 ANC 216

69 ANC 22OB

69 ANC $221 \mathrm{~B}$

69 ANC $222 \mathrm{~F} \mathrm{II}$

69 ANC 2224 I

69 ANC 223

69 ANC 223

69 ANC 224A

69 ANC 224B

69 ANC 227B

69 ANC 229

69 ANC 230

69 ANC 230

69 ANC 232

69 ANC 235

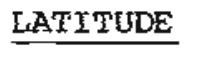

LONGITUDE

$63^{\circ} 41^{\prime}$

$170^{\circ} 0^{\prime}$

" $"$

$63^{\circ} 43^{\prime} 42^{\prime \prime}$

" 1

$n$

11

$63^{\circ} 42^{\prime} 36^{\prime \prime}$

$63^{\circ} 53^{\prime} 24^{4}$

$63^{\circ} 54^{\prime}$

i)

$64^{\circ} 0^{\prime} 54^{\prime \prime}$

$63^{\circ} 51$ ' $18^{\prime \prime}$

$63^{\circ} 52^{\prime} 18^{\prime \prime}$

$63^{\circ} 56^{\prime} 48^{\prime \prime}$

H

$64^{\circ} 0^{\prime} 54^{\prime \prime}$

a

$63^{\circ} 58^{\prime} 18^{\prime \prime}$

" "

$64^{\circ} 8^{\prime} 12^{m}$

$64^{\circ} 8^{\prime} 6^{\prime \prime}$

$64^{\circ} 13^{\prime}$

" $"$

$64^{\circ} 15^{\prime} 30^{\prime \prime}$

$64^{\circ} 29^{\prime} 54^{n}$
WATER DEPTH

I44'

"

$138^{\prime}$

11

11

$125^{\prime}$

105'

$93^{\prime}$

st

$89^{\prime}$

$125^{\prime}$

177

$180^{\prime}$

H

$184^{\prime}$

r

$177^{\prime}$

it

$159^{\prime \prime}$

$118^{\prime \prime}$

$118^{\prime}$

II

$125^{\prime}$

121
VAIUE PPM GG

$$
0.03
$$

0.03

0.14

$<0.01$

0.01

0.05

$<0.01$

0.01

$<0.01$

0.02

0.01

$<0.01$

0.10

0.06

0.23

0.03

0.01

0.03

0.06

0.04

0.02

0.04

0.04

0.01

\section{REMARKS}

Offshore surface

offshore Subsurface

offshore surface

II

Offshore Subsurface

Offshore surface

" 1

"

Offshore subsurface Offshore surface

" 1

11

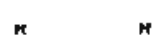

Offshore Subsurface

Offshore surface

offghore subgurface

offshore surface

11

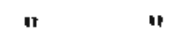

$\pi$

n n

Offshore subsurface

Offshore surface 


\section{SAMPLE NUMBER}

69 ANC 237

69 ANC 237

69 ANC 245H II

69 ANC $245 \mathrm{H} \mathrm{I}$

69 ANC 247H VII

69 ANC 2508

69 ANC 25 IS

69 ANC 251T

69 ANC 25IB

59 ANC 252H IV

69 ANC $252 \mathrm{H} \mathrm{IV}$

๙ 69 ANC 252H IV

69 ANC 252H IV

69 ANC $252 \mathrm{H} \mathrm{IV}$

69 ANC $252 \mathrm{H} \mathrm{IV}$

69 ANC 252H II

69 ANC 252H II

69 ANC 252H II

69 ANC $252 \mathrm{H}$ II

69 ANC $252 \mathrm{H} \mathrm{II}$ 69 ANC 252ध I

69 ANC 252H I

69 ANC $252 \mathrm{H} \mathrm{I}$

69 ANC $252 \mathrm{H} \mathrm{I}$

\begin{tabular}{|c|c|c|}
\hline IATI & ETUDE & LONGITUDE \\
\hline $65^{\circ}$ & $4^{\prime} 30^{\prime \prime}$ & $169^{\circ} 14^{\prime} 42^{n}$ \\
\hline 4 & u & $"$ \\
\hline $65^{\circ} \mathrm{I}$ & $11^{\prime} 12^{\prime \prime}$ & $167^{\circ} 53^{\prime} 12^{\prime \prime}$ \\
\hline H & " & " \\
\hline $\left.65^{\circ}\right]$ & $13 \cdot 54^{\prime \prime}$ & $167^{\circ} 39^{\prime} 30^{\prime \prime}$ \\
\hline $65^{\circ}$ & $7 \cdot 24 "$ & $167^{\circ} 30^{\circ}$ \\
\hline $65^{\circ}$ & $6^{\prime} 18^{\prime}$ & $167^{\circ} 37^{\prime} 12^{+1}$ \\
\hline$n$ & $"$ & $"$ \\
\hline$"$ & $"$ & " \\
\hline $65^{\circ}$ & $5^{\prime} 6^{\prime \prime}$ & $167^{\circ} 43^{\prime} 24^{\prime}$ \\
\hline n & ! & " 13 \\
\hline$"$ & $"$ & $"$ \\
\hline$n$ & י & $"$ \\
\hline$\pi$ & $"$ & $n$ \\
\hline$n$ & $n$ & $"$ \\
\hline$"$ & $"$ & " \\
\hline$"$ & $n$ & n \\
\hline$H$ & M & Is \\
\hline$"$ & $"$ & $"$ \\
\hline " & $"$ & $"$ \\
\hline 17 & "T & " \\
\hline n & " & * 1 \\
\hline$"$ & $"$ & $"$ \\
\hline$"$ & $"$ & $"$ \\
\hline
\end{tabular}

$164^{\prime \prime}$

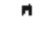

$102^{\prime}$

"

1.1.8

$56^{\prime}$

$69^{\prime}$

"

$"$

$120^{\prime}$

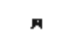

"

"

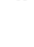

"

n

"

n

H

"

"

n

n

"

"
VALUE PPM HG

0.03

0.03

0.03

0.04

0.03

0.02

0.03

0.02

0.01

0.28

0.08

0.05

0.03

0.02

0.03

0.12

0.04

0.05

0.02

0.04

0.28

0.08

0.01

0.03
FEMARKS

offshore Surface

offshore subsurface

offishore Surface

offshore subsurface

offshore surface

Offshore subsurface

offshore Surface

offshore subsurface

Offshore Surface, lst Trial

$\begin{array}{lll}" & \text { " } & \text { 2nd Trial } \\ " & \text { " } & \text { 3rd Trial } \\ " & \text { " } & 4 \text { th Trial } \\ \text { " } & \text { " } & 6 \text { th Trial } \\ \text { " } & \text { "trial }\end{array}$

Offshore Upper Subsurface, lst Trial

" " " 2nd Trial

" $"$ " 3 ra Trial

" " "4th Trial

" " " " 5th Trial

Offishore Lower subsurface, lst Irial

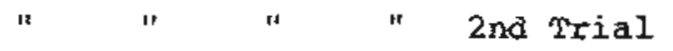

" " " $" 3 r d$ Trial

" " " 4th Trial 


\begin{tabular}{|c|c|c|c|c|c|c|c|c|c|c|c|c|}
\hline \multicolumn{2}{|c|}{ SAMFLE } & \multirow{2}{*}{$\frac{\text { NUMBER }}{252 \mathrm{H} \mathrm{I}}$} & \multirow{2}{*}{$\begin{array}{l}\text { LATITUDE } \\
65^{\circ} 5^{\prime} 6^{\prime \prime}\end{array}$} & \multirow{2}{*}{$\begin{array}{l}\text { LONGITUDE } \\
167^{\circ} 43^{\prime} 24^{\prime \prime}\end{array}$} & \multirow{2}{*}{$\frac{\text { WATER DEPTH }}{120^{\prime}}$} & \multirow{2}{*}{$\frac{\text { VALUE PPM HG }}{0.01}$} & \multicolumn{6}{|c|}{ REMARKS } \\
\hline 69 & ANC & & & & & & offshore & Lower & Subs & surfa & ace, 5 & 5th Trial \\
\hline 69 & ANC & $252 \mathrm{HI}$ & " $"$ & $"$ & $"$ & 0.03 & $"$ & $"$ & $"$ & & $"$ & 6th Trial. \\
\hline 69 & ANC & $253 \mathrm{~S}$ & $65^{\circ} 5^{\prime} 24^{\prime \prime}$ & $167^{\circ} 47^{\prime}$ & $102^{\prime}$ & 0.01 & Offshore & Surfac & & & & \\
\hline 69 & ANC & $253 \mathrm{~B}$ & $"$ & $"$ & $"$ & 0.02 & offshore & Subsux & face & & & \\
\hline 69 & ANC & $253 \mathrm{BC}$ & $"$ & $"$ & $1 "$ & 0.01 & offshore & & & & & \\
\hline 69 & ANC & $253 \mathrm{BB}$ & " " " & " & $"$ & 0.01 & offshore & & & & & \\
\hline 69 & ANC & $254 \mathrm{~B}$ & $65^{\circ} 1^{\prime} 36^{\prime \prime}$ & $168^{\circ} 5^{\prime} 30^{\prime \prime}$ & $112^{\prime}$ & 0.01 & offshore & Surfac & & & & \\
\hline 69 & ANC & $255 \mathrm{UH}$ & $64^{\circ} 57^{\prime}$ & $168^{\circ} 15^{\prime}$ & $134^{\prime}$ & 0.03 & $"$ & $"$ & & & & \\
\hline 69 & ANC & 255 LH & $"$ & " " " & $"$ & 0.05 & offshore & Subsux & face & & & \\
\hline 70 & ANC & $7 \mathrm{~B}$ & $63^{\circ} 17^{\prime} 30^{\prime \prime}$ & $172^{\circ} 18^{\prime}$ & $202^{\prime}$ & 0.16 & offshore & Surfac & $=e, 1$ & Iat T & Trial & \\
\hline 70 & ANC & $7 \mathrm{~B}$ & $"$ & $"$ & $"$ & 0.04 & $"$ & $"$ & & 2 nd $T$ & Trial & \\
\hline 70 & $\mathrm{ANC}$ & $7 \mathrm{~B}$ & $"$ & $"$ & $"$ & 0.01 & $"$ & $"$ & & 3 rd $T$ & Trial & \\
\hline 70 & ANC & $7 \mathrm{~B}$ & $"$ & $"$ & $"$ & 0.01 & $"$ & $"$ & & 4th $\mathrm{T}$ & Trial & \\
\hline 70 & ANC & $7 \mathrm{~B}$ & $"$ & $"$ & $"$ & 0.03 & $"$ & $"$ & & 5 th $\mathrm{T}$ & Trial & \\
\hline 70 & ANC & 11. B & $63^{\circ} 18^{\prime} 30^{\prime \prime}$ & $170^{\circ} 55^{\prime} 54^{\prime \prime}$ & $B 8^{\prime}$ & 0.06 & offshore & surfac & & & & \\
\hline 70 & ANC & $13 \mathrm{~B}$ & $63^{\circ} 8^{\prime} 12^{\prime \prime}$ & $170^{\circ} 28^{\prime}$ & I24' & $<0.01$ & " & $"$ & & & & \\
\hline 70 & ANC & $14 \mathrm{~B}$ & $62^{\circ} 54^{\prime} 48^{\prime \prime}$ & $170^{\circ} 36^{\prime} 48^{\prime \prime}$ & $139^{\circ}$ & 0.06 & $"$ & $"$ & & & & \\
\hline 70 & ANC & $15 \mathrm{~S}$ & $62^{\circ} 57^{\prime} 42^{\prime \prime}$ & $170^{\circ} 27^{\prime} 24^{\prime \prime}$ & $147^{\prime}$ & 0.06 & $"$ & $"$ & & & & \\
\hline 70 & ANC & $15 \mathrm{~B}$ & $" \quad "$ & " " & $"$ & 0.09 & Offshore & Subsul & tface & & & \\
\hline 70 & ANC & 165 & $62^{\circ} 54^{\prime}$ & $169^{\circ} 58^{\circ}$ & I $37^{\prime}$ & 0.01 & offshore & surfar & & & & \\
\hline 70 & ANC & $20 s$ & $62 \circ 37 ' 18^{\prime \prime}$ & $169^{\circ} 24^{\prime}$ & $115^{\prime}$ & $<0.01$ & $"$ & $"$ & & & & \\
\hline 70 & ANC & $24 S$ & $63^{\circ} 10^{\prime}$ & $168^{\circ} 38^{\prime}$ & $88 '$ & 0.04 & $"$ & $"$ & & & & \\
\hline 70 & ANC & $27 \mathrm{~B}$ & $63^{\circ} 9^{\prime} 36^{\prime \prime}$ & $167^{\circ} 56^{\circ} 54^{\prime \prime}$ & $77^{\prime}$ & $<0.01$ & $"$ & $"$ & & & & \\
\hline 70 & ANC & $29 \mathrm{~s}$ & $62 \circ 52^{\prime}$ & $167^{\circ} 4^{\prime}$ & $91^{\prime}$ & 0.07 & $"$ & $n$ & & & & \\
\hline
\end{tabular}




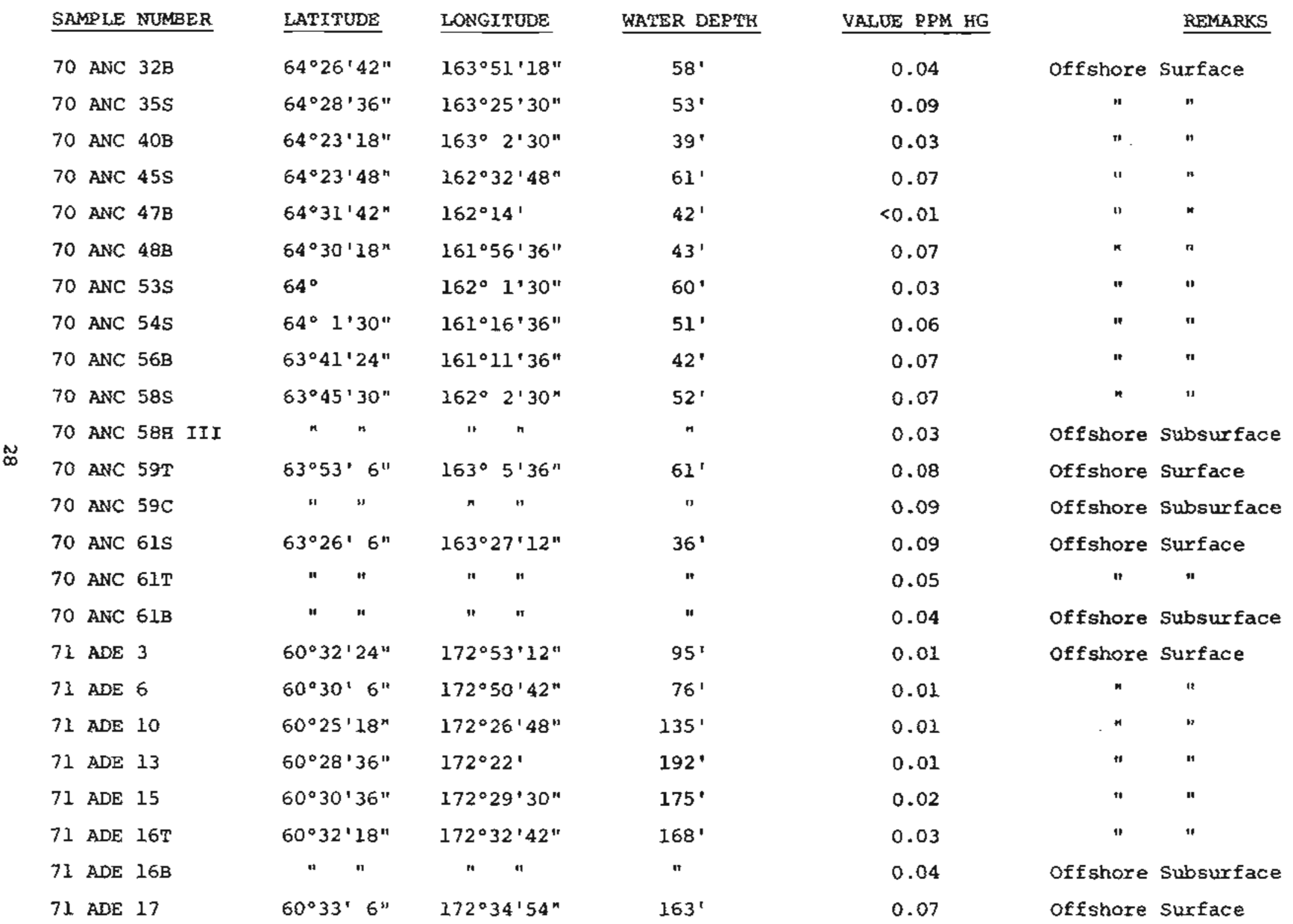




\section{SAMPLE NUMBER}
71 ADE 19
71 ADE 20
71 ADE 22
71 ADE 26
71 ADE 30
71 ADE 32
$71 \mathrm{ADE} 35$
71 ADE 36
71 ADE 38

LATITUDE $\quad$ LONGITUDE

$60^{\circ} 35^{\prime} 54^{\prime \prime}$

$172^{\circ} 42^{\prime} 42^{\prime \prime}$

$60^{\circ} 32^{1} 30^{\prime \prime}$

$172^{\circ} 47^{\prime} 36^{\prime \prime}$

$60^{\circ} 29^{\prime} 24^{\prime \prime}$

$172^{\circ} 41^{\prime} 24^{n}$

$60^{\circ} 24^{\prime} 42^{\prime \prime} \quad 172^{\circ} 34^{\prime} 12^{\prime \prime}$

$60^{\circ} 20^{\prime} 12^{\prime \prime}$

$172^{\circ} 25^{\prime} 30^{\prime \prime}$

$60^{\circ} 23^{\prime} 30^{\prime \prime}$

$60^{\circ} 36^{\prime} 12^{\prime \prime}$

$172^{\circ} 4 B^{\prime}$

$60^{\circ} 37$ ' 48 "

$60 \cdot 38^{\prime} 54 "$

$172^{\circ} 53^{\prime} 54^{\prime \prime}$

$172^{\circ} 58^{\circ} 6 "$

$173^{\circ} 3^{\prime} 42^{\prime \prime}$
WATER DEPTH

$146^{\prime \prime}$

132 '

$92{ }^{\prime}$

$93^{r}$

$42^{\circ}$

$42^{\prime \prime}$

$117^{\prime}$

$120^{\prime}$

$50^{\prime}$
VALUE PPM HG

0.05

0.04

0.02

0.03

0.05

0.01

0.01

$<0.01$

0.01
REMARKS

offahore surface

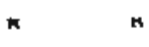

"1.

a

"

"

"

"

" " 


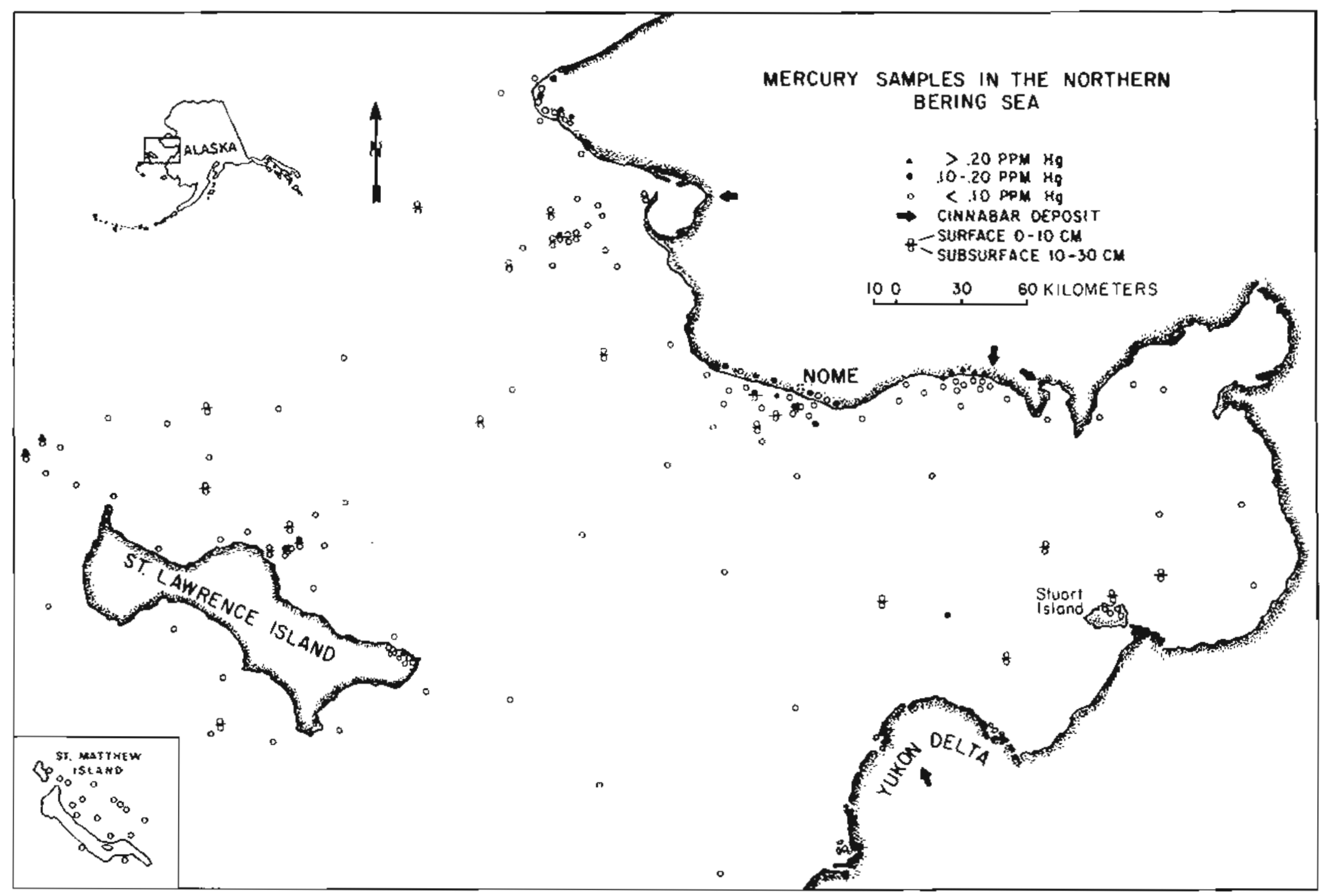


":

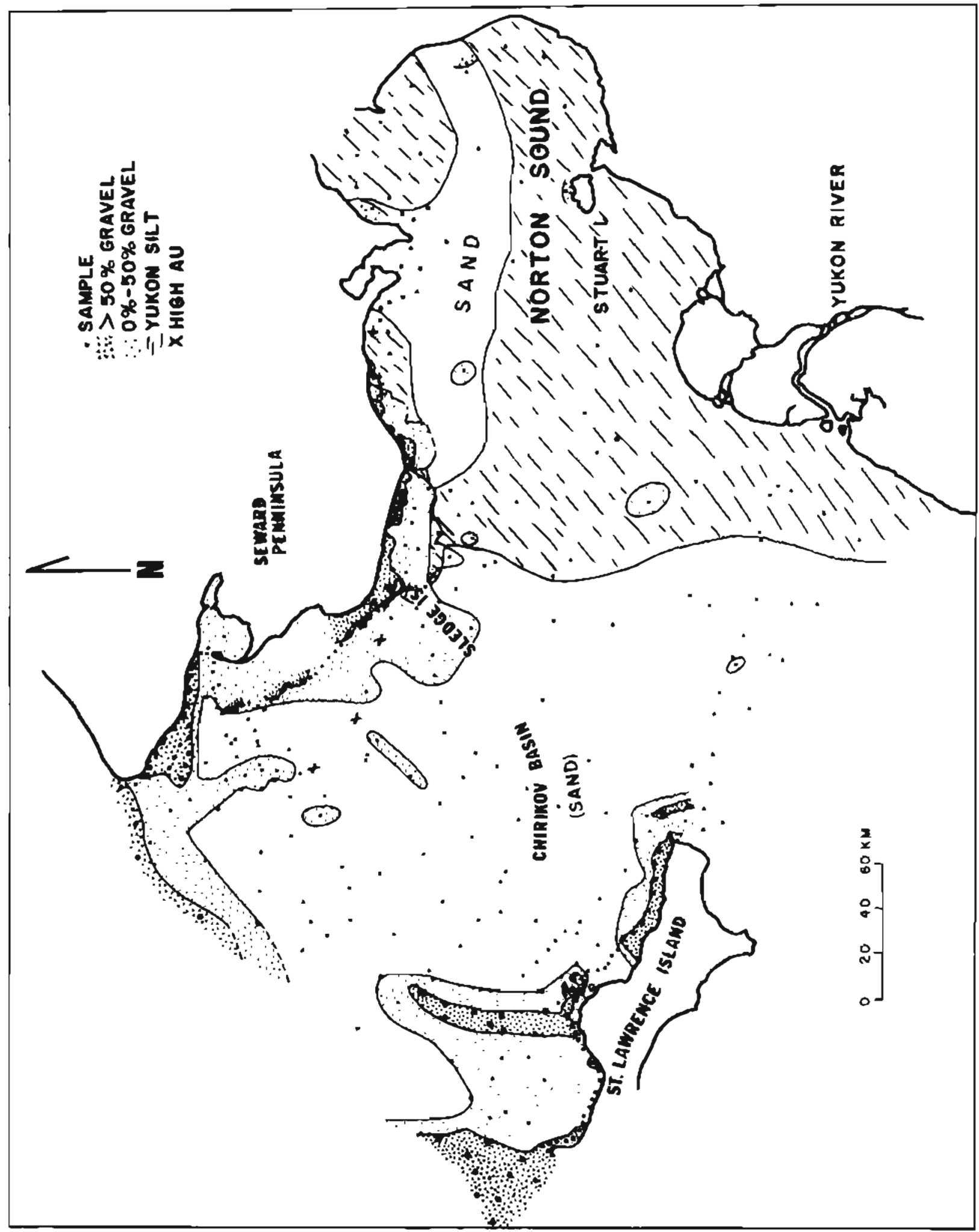



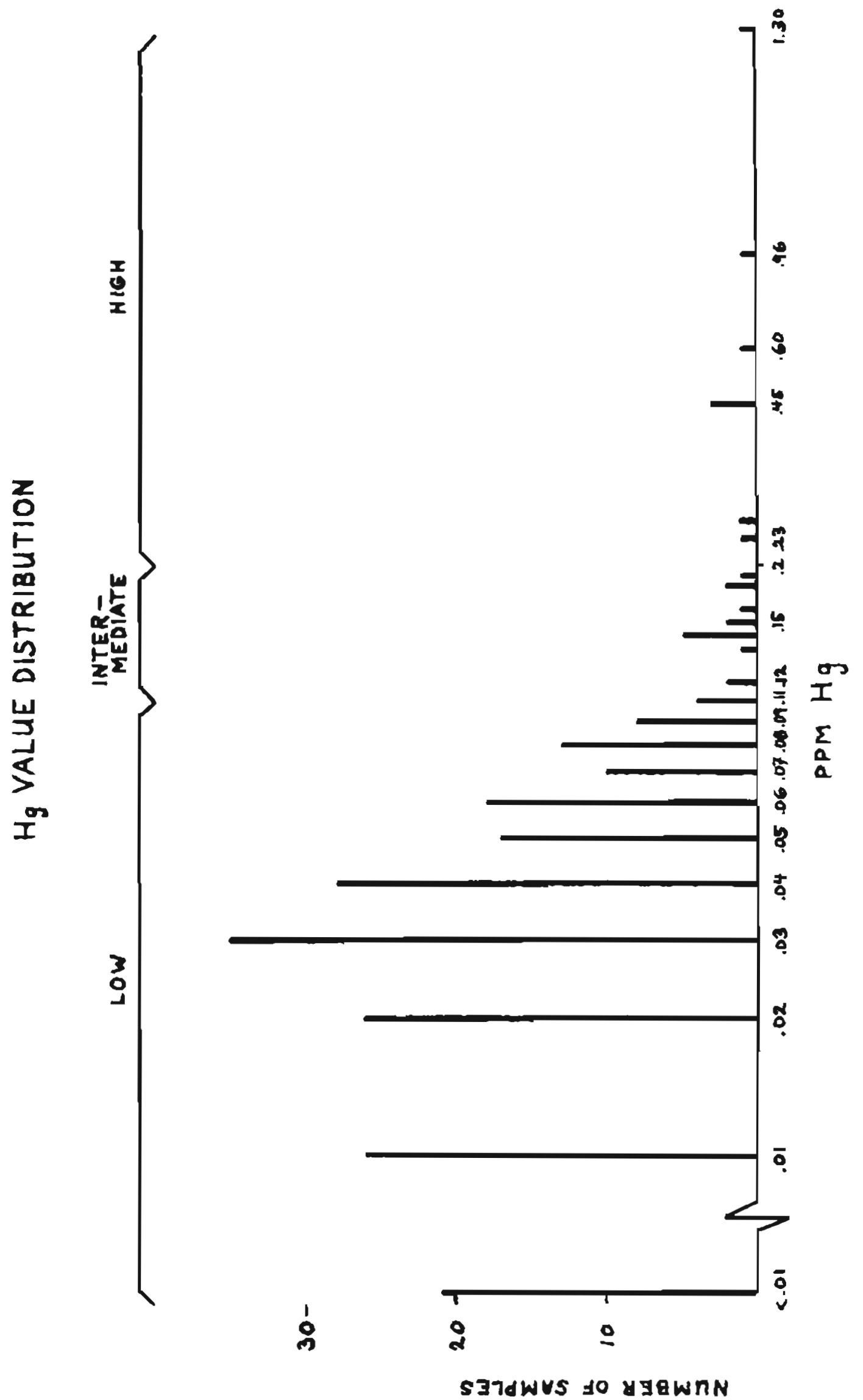
MERCURY CONCENTRATION

(PPM OF DRY SAMPLE WT.)

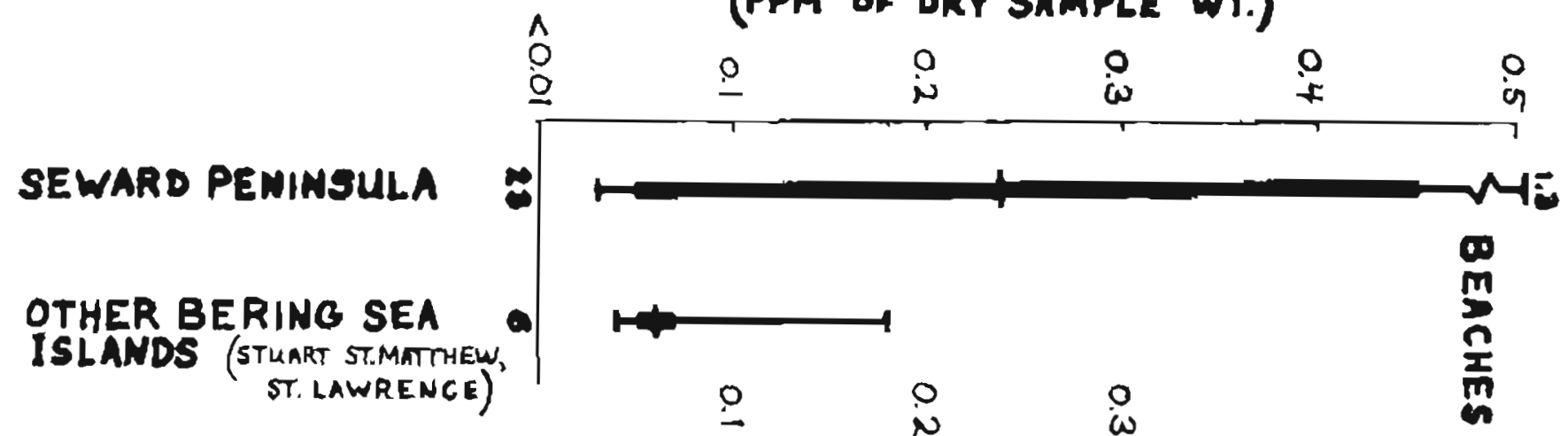

$>40 \mathrm{KM}$ FROM ALL SHORELINES

$<40$ KM FROM ALL SHORELINES

$<20 \mathrm{KM}$ FROM

SEWARD PENIN SULA

<2OKM FROM BERINE SEA ISLANDS (STUART ST. MATTHEWS, ST. LAWRENCE)
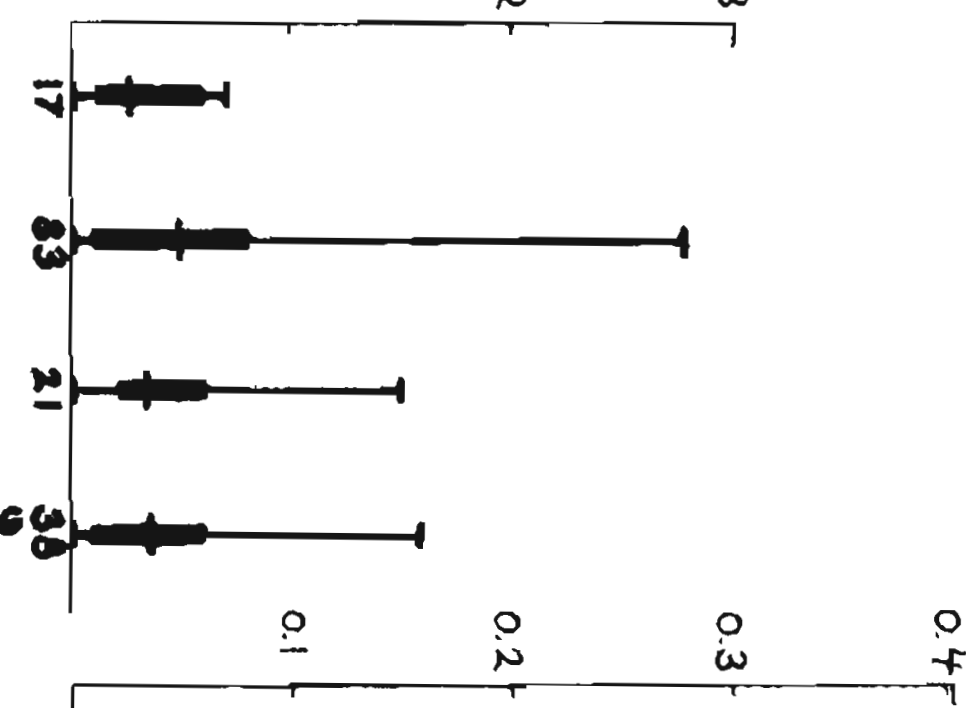

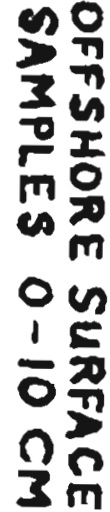

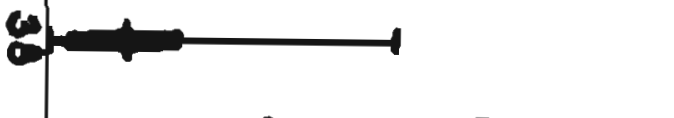

$>40 \mathrm{KM}$ FROM ALL SHORELINES

$<40$ KM FROM ALL SHORELINES

$<20 \mathrm{KM}$ FROM SEWARD PENINSULA

$\angle 20 \mathrm{KM}$ FROM BERIMO SEA ISLANDS (STUART, ST. LAWRENCE, ST. MATHEW) DRILL HOLES 0-244'

\section{SEWARD PENINS}

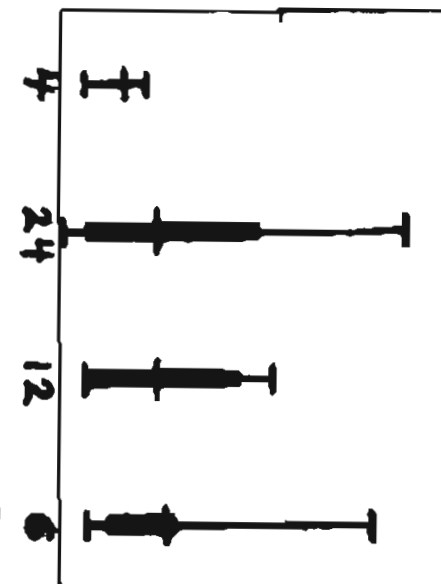

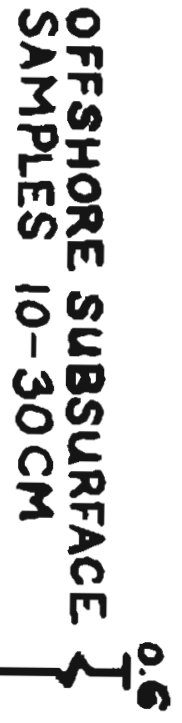

